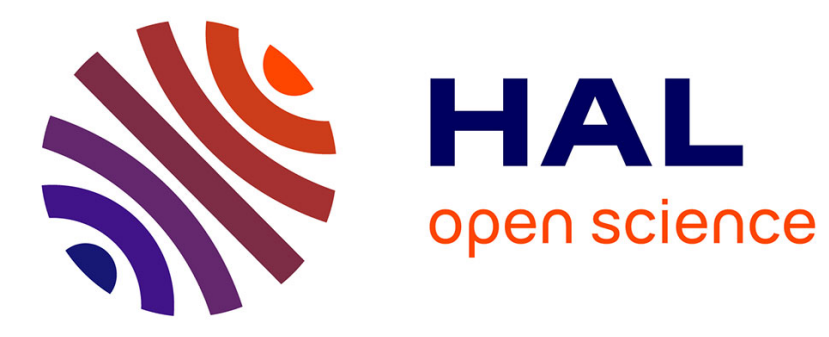

\title{
Bronze Age iron: Meteoritic or not? A chemical strategy.
}

Albert Jambon

\section{To cite this version:}

Albert Jambon. Bronze Age iron: Meteoritic or not? A chemical strategy.. Journal of Archaeological Science, 2017, 10.1016/j.jas.2017.09.008 . hal-01614724

\section{HAL Id: hal-01614724 https://hal.sorbonne-universite.fr/hal-01614724}

Submitted on 11 Oct 2017

HAL is a multi-disciplinary open access archive for the deposit and dissemination of scientific research documents, whether they are published or not. The documents may come from teaching and research institutions in France or abroad, or from public or private research centers.
L'archive ouverte pluridisciplinaire HAL, est destinée au dépôt et à la diffusion de documents scientifiques de niveau recherche, publiés ou non, émanant des établissements d'enseignement et de recherche français ou étrangers, des laboratoires publics ou privés. 


\title{
Bronze Age Iron: Meteoritic or not? A Chemical Strategy.
}

\author{
Albert JAMBON 1,2 \\ ${ }^{1}$ Université Côte d'Azur, UPMC, CNRS, OCA, IRD, Géoazur, Sophia Antipolis, France \\ ${ }^{2}$ Sorbonne Universités, UPMC Univ Paris 06, MNHN and IMPMC, France
}

albert.jambon@upmc.fr

\begin{abstract}
Bronze Age iron artifacts could be derived from either meteoritic (extraterrestrial) or smelted (terrestrial) iron. This unresolved question is the subject of a controversy: are some, all or none made of smelted iron? In the present paper we propose a geochemical approach, which permits us to differentiate terrestrial from extraterrestrial irons. Instead of evaluating the $\mathrm{Ni}$ abundance alone (or the $\mathrm{Ni}$ to $\mathrm{Fe}$ ratio) we consider the relationship between $\mathrm{Fe}, \mathrm{Co}$ and $\mathrm{Ni}$ abundances and their ratios. The study of meteoritic irons, Bronze Age iron artifacts and ancient terrestrial irons permit us to validate this chemical approach. The major interest is that non-invasive p-XRF analyses provide reliable Fe:Co:Ni abundances, without the need to remove a sample; they can be performed in situ, in the museums where the artifacts are preserved. The few iron objects from the Bronze Age sensu stricto that could be analyzed are definitely made of meteoritic iron, suggesting that speculations about precocious smelting during the Bronze Age should be revised. In a Fe:Co:Ni array the trend exhibited by meteoritic irons departs unambiguously from modern irons and iron ores. The trend of $\mathrm{Ni} / \mathrm{Fe}$ vs $\mathrm{Ni} / \mathrm{Co}$ in different analysis points of a single object corroded to variable extents provides a robust criterion for identifying the presence of meteoritic iron. It opens the possibility of tracking when and where the first smelting operations happened, the threshold of a new era. It emphasizes the importance of analytical methods for properly studying the evolution of the use of metals and metal working technologies in our past cultures.
\end{abstract}

Keywords: Iron, Bronze Age, Iron Age, meteorite, iron ore

\section{Introduction}

Paradoxically, a number of iron artifacts from the Bronze Age have been found in a variety of Old World culture areas (e.g. Li Chung 1979; Waldbaum 1980, 1999 and references therein; Yalçin 1999; Jean 2001) with the recurrent question about the origin of the iron: extraterrestrial (meteoritic) or terrestrial (smelted)? "Bronze Age Iron" means iron that appears within Old World culture areas, prior to the advent of iron smelting on some scale in those areas.

The two possibilities are supported by a number of valuable arguments which are summarized as follows: Nickel (Ni) is the signature element for meteoritic iron. The Ni content is sometimes too low to be meteoritic which could be explained either by the use of $\mathrm{Ni}$ rich iron ores $(\mathrm{Ni}$ poor relative to meteorites) or by weathering with preferential loss of $\mathrm{Ni}$. The confusion is increased by some conflicting results on the same artifacts by different methods at different times, with the difficulty that metallographic analyses which could solve this contention are impossible on such rare and fragile objects (On Line
Supplementary Material: A1 Meteoritic vs. Terrestrial Iron: a controversy).

In this work we examine a new geochemical approach involving the analysis of three elements (Fe:Co:Ni) instead of two (Fe:Ni) with the aim of differentiating between the above mentioned possibilities. This is enabled by the recent development of high performance portable XRF analyzers (see On Line Supplementary Material : A2 Analytical methods). Our argument proceeds as follows:

- Consider a data set of meteoritic irons, including oxidized specimens.

- Analyze irons of diverse ages: Bronze Age, Bronze to Iron Age transition and Iron Age, and take benefit of recent high quality analyses (see On Line Supplementary Material : A3. Samples). Iron ore compositions are also considered. Lateritic alteration products derived from peridotitic rocks are common from Croatia to Greece, Turkey, Iran, Cyprus ... These may be valuable iron ores and contain significant amounts of $\mathrm{Co}$ and $\mathrm{Ni}$ unlike sedimentary iron ores which are more common in western Europe 
(see On Line Supplementary Material : A3.6. Iron ores). Since Brun in Schaeffer (1939) suggested that the $13^{\text {th }}$ century BCE Ugarit (Syria) iron axe could be derived from iron sulfide ore (pyrrhotite $\mathrm{Fe}_{1-\mathrm{x}} \mathrm{S} ; \mathrm{x}=0$ to 0.2 ), such material will be considered in this study using data from the literature (Bamba, 1981).

\section{Results}

2.1 Iron meteorites: The analytical results for polished surfaces of iron meteorites, outer oxidized surfaces of iron meteorites (OLSM table A1) and literature compositions for different classes of iron meteorites are presented in figure 1, in addition to a compilation of iron meteorite compositions from the Meteoritical Bulletin database (http://www.lpi.usra.edu/meteor/): 176 meteorites classified from 1986 to 2016 (OLSM, table A2). The variations within this population are best illustrated in a Ni/Fe vs Ni/Co diagram (Fig. 1).

Fresh meteorites exhibit a Ni/Fe range from 0.058 to 0.40 (average 0.102 ) whereas oxidized/weathered surfaces of iron meteorites exhibit lower values down to 0.009 . We checked that the variations observed are not due to the variability within one single

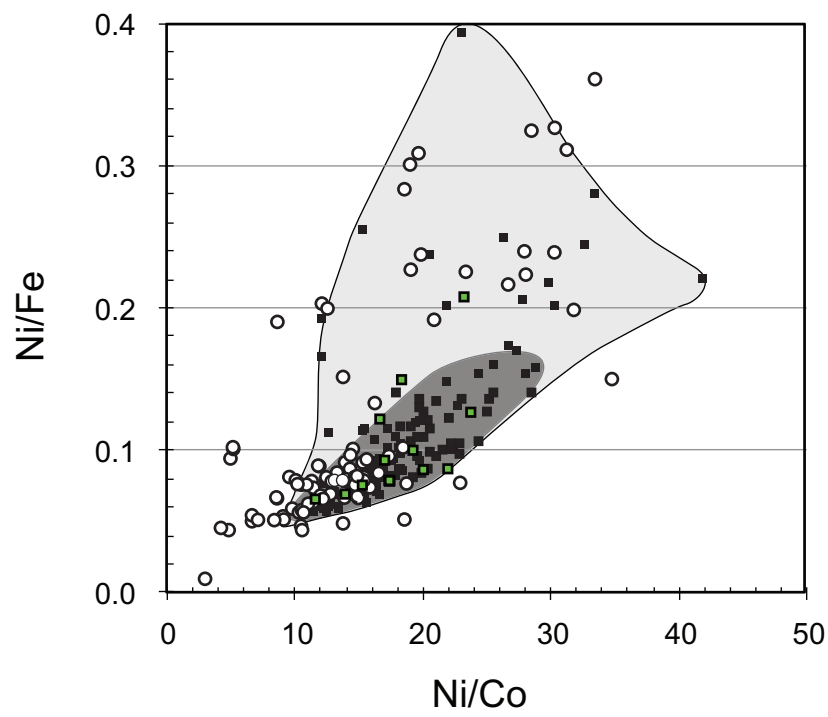

Fig. 1. $\mathrm{Ni} / \mathrm{Fe}$ vs $\mathrm{Ni} / \mathrm{Co}$ in iron meteorites. Black squares and gray area are from literature data for fresh iron meteorites. Green squares: average compositions of the major iron meteorite groups (Mittlefehldt et al. 1998). White circles: p-XRF analyses of both polished and oxidized outer surface (this work). P-XRF measurements on fresh surfaces are similar to literature data. On the average, oxidized compositions extend to slightly lower $\mathrm{Ni} / \mathrm{Co}$ and $\mathrm{Ni} / \mathrm{Fe}$ ratios. $80 \%$ of the data for fresh meteorites are enclosed in the high-density field (dark gray). (http://www.Ipi.usra.edu/meteor/)

meteorite as illustrated by the results for Morasko meteorite, which we could analyze in 31 points, hence assessing the internal variability of its Co and $\mathrm{Ni}$ content, and the different compositions of fresh and weathered surface. The results obtained for fresh metal surfaces is within the range of those reported in the literature (NAA analysis of large samples, Pilski et al. 2013) with restricted standard deviations smaller than the variability range observed for the whole data set (On line supplementary Material; A3.2 Iron meteorites)

Surfaces oxidized during the atmospheric flight exhibit similar ratios. The case is different for finds, which have been weathered. This indicates that during weathering, a surficial layer is impoverished in $\mathrm{Ni}$ relative to $\mathrm{Fe}$ whence the $\mathrm{Ni} / \mathrm{Fe}$ ratio cannot be used as a reliable indicator of the meteorite type for weathered samples. A comparable variation is observed for the $\mathrm{Ni} / \mathrm{Co}$ ratio. Notice that the chemical properties relative to weathering are in the order $\mathrm{Fe}>\mathrm{Co}>\mathrm{Ni}$, whence the positive correlation between $\mathrm{Ni} / \mathrm{Fe}$ and $\mathrm{Ni} / \mathrm{Co}$ as will be better illustrated in the following subsection for the case of the Ugarit axe, analyzed in different spot analyses (Fig. 2). It follows that the $\mathrm{Ni} / \mathrm{Fe}$ ratio alone cannot be used as an indicator of the source of iron.

\subsection{Bronze Age archaeological artifacts:}

Analytical results are listed in the on line supplementary material, table A4 with references to where a description can be found. Additional information can be found in OLSM section A4.1.

Ugarit axe (Syria 1400 BCE).

We performed ten spot analyses at different places on both sides of the blade (see Jambon et al. 2017). The $\mathrm{Ni}$ concentrations of 1.7 up to $7.6 \% \mathrm{Ni}$ (calculated on an oxygen free basis) document nicely the effect of weathering. The high $\mathrm{Ni}$ contents are undoubtedly the signature of meteoritic iron whereas the lowest values correspond to pervasively oxidized spots. These differences probably result from rust flakes detachment from the surface. The variations of $\mathrm{Ni} / \mathrm{Co}$ and $\mathrm{Ni} / \mathrm{Fe}$ correlate fairly well with $\mathrm{Ni}$ content, which can be viewed as an index of weathering, as displayed in figure 2. The $\mathrm{Ni} / \mathrm{Fe}$ and $\mathrm{Ni} / \mathrm{Co}$ ratios plot on the trend defined previously for iron meteorites, figure 3 , which is interpreted as corresponding to different degrees of weathering. Our results for the Ugarit axe show both higher and lower $\mathrm{Fe} / \mathrm{Ni}$ ratios compared to the analysis reported in Schaeffer (1939). The sampling made by Schaeffer being undocumented, we assume that it was a surface chip, an average of more and less oxidized material, but no obvious mark of sampling is presently visible on the axe blade. 


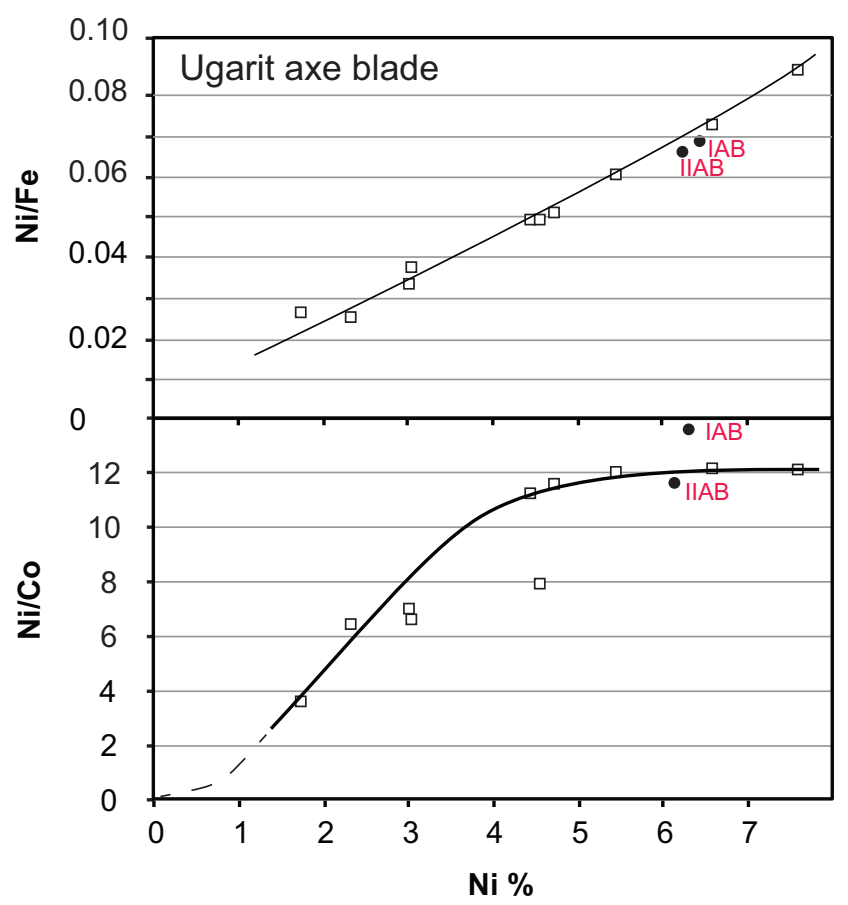

Fig 2. Plot of $\mathrm{Ni} / \mathrm{Fe}$ and $\mathrm{Ni} / \mathrm{Co}$ against $\mathrm{Ni}$ abundance for Ugarit Axe. The steady variation of the $\mathrm{Ni} / \mathrm{Fe}$ ratio against $\mathrm{Ni}$ indicates that $\mathrm{Ni}$ is preferentially leached during weathering whereas, $\mathrm{Fe}$ oxidized to $\mathrm{Fe}^{3+}$ is not. The $\mathrm{Ni} / \mathrm{Co}$ ratio remains constant for mild weathering and then decreases when part of $\mathrm{Co}$ is oxidized to $\mathrm{Co}^{3+}$. Average composition of $\mathrm{IAB}$ and IIAB meteorites are plotted for reference.

\section{Other Bronze Age artifacts.}

The results for the Gerzeh beads (Egypt; 3200 BCE), Umm el Marra pendant (Syria; 2300 BCE), Tuts dagger, bracelet and headrest (Egypt; 1350 BCE), Shang Dynasty axes (China; 1400 BCE) and Alaca Höyük dagger, (Turkey; 2500 BCE) are commented in detail in the On line supplementary Material; A4.1. The only specimen for which one single analysis is available is Tut's dagger the meteoritic origin of which is beyond any doubt (Comelli et al. 2016; Ströbele et al. 2016). For all other specimens we have 2 to 9 analytical points. Both $\mathrm{Co}$ and $\mathrm{Ni}$ are highly variable $(0.8$ to $8.5 \% \mathrm{Ni})$ but in the $\mathrm{Ni} / \mathrm{Fe}$ vs. Ni/Co plot, figure 3 , the data points fall nicely on the same trend as Ugarit axe data. For some of the artifacts the highest $\mathrm{Ni}$ concentrations are in the range of meteoritic values (e.g. Gerzeh beads, Alaca Höyük dagger, Tut's jewelry) while some data points fall below $3.5 \% \mathrm{Ni}$. Taken at face value and if the conservative threshold of $5 \% \mathrm{Ni}$ were considered (e.g. Yalçin, 1999), one would infer the presence of both terrestrial and meteoritic iron in one and the same sample!

In the present interpretation however, replicate analyses including Co analyzes, indicate that all artifacts tested are made of meteoritic iron. For the other artifacts (e.g. Umm el Marra pendant, Shang axe) the low $\mathrm{Ni}$ concentrations cannot therefore be considered as a proof of being terrestrial. The data points falling on the same correlation as meteoritic artifacts strongly suggests that they are meteoritic as well. In other words, the

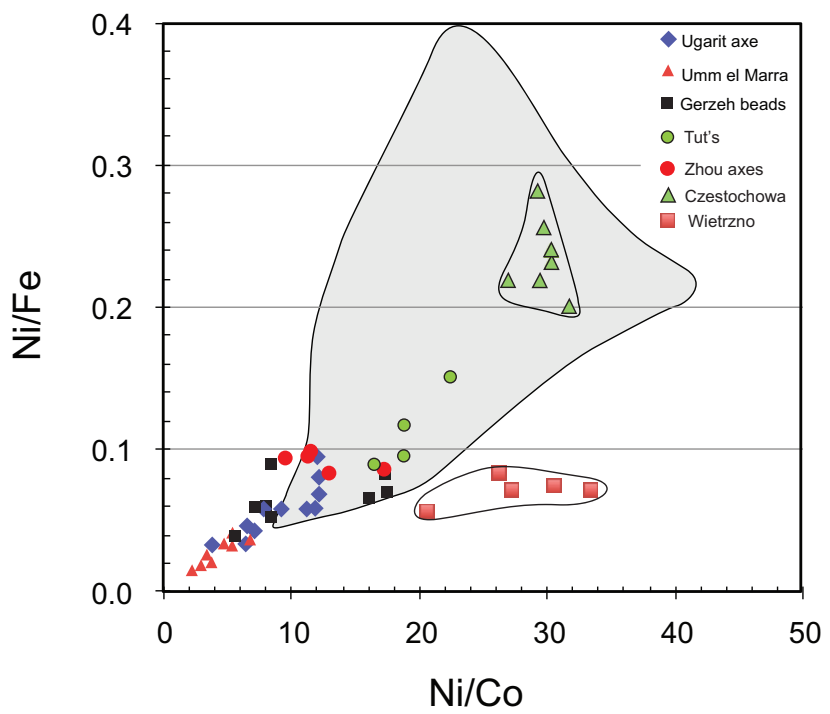

Fig 3. Same as figure 1 for Bronze Age and Iron Age iron artifacts. The gray area is taken as a reference from figure 1. Most compositions are clearly displaced to lower $\mathrm{Ni} / \mathrm{Co}$ and $\mathrm{Ni} / \mathrm{Fe}$ values. Well documented specimens like Umm el Marra pendant and Ugarit axe exhibit a clear positive correlation corresponding to variable extents of weathering, undistinguishable from the bulk trend. Tut's dagger and Gerzeh beads, which have been demonstrated to be of meteoritic origin fall on the same correlation. This work, except Tut's, Alaça Höyük and Zhou axes data taken from the literature. Notice the apparent out-of place field for Wiertzno axe.

$\mathrm{Ni} / \mathrm{Fe}$ ratio alone is not appropriate to conclude whether an artifact is made of meteoritic iron or not, or may be the threshold should be dramatically decreased. This indicates that the weathered surface exhibits variable $\mathrm{Ni} / \mathrm{Fe}$ and $\mathrm{Ni} / \mathrm{Co}$. The trend for artifacts is similar to that observed for weathered meteorites with lower $\mathrm{Ni} / \mathrm{Fe}$ and $\mathrm{Ni} / \mathrm{Co}$ on the average. This is not surprising since the meteorites analyzed were only marginally weathered. To summarize, the range in both $\mathrm{Ni} / \mathrm{Fe}$ and $\mathrm{Ni} / \mathrm{Co}$ for meteorites and iron artifacts overlap, with a significant variability in $\mathrm{Ni} / \mathrm{Fe}$ and possibly low $\mathrm{Ni}$ contents (down to less than 1\%). According to the present observations, none of the $\mathrm{Ni}$ bearing iron artifacts, with low $\mathrm{Ni}$ content, was proved to be made of terrestrial iron.

Our preliminary conclusions may therefore read :

1) All results, the present $p-X R F$ analyses and literature results as well, illustrate than one single object may exhibit various $\mathrm{Ni}$ contents depending on the analytical spot. This is not due to primordial metal heterogeneity but rather to a variable extent of weathering (corrosion). Most of us 
will agree that contents exceeding $5 \% \mathrm{Ni}$ should be considered as meteoritic; the lower $\mathrm{Ni}$ contents from the same objects, especially when analyzed with the same technique, must be considered meteoritic as well.

2) When the Co results are considered, even though the $\mathrm{Ni}$ data alone could appear inconclusive, the Fe:Co:Ni correlation falls on one and the same trend with iron meteorites. Weathering is an important factor of variation in the $\mathrm{Ni}$ content. One way of accounting for this effect is to consider the Fe:Ni:Co correlations.

3) No nickel-poor iron from the Bronze age can be proved not to be meteoritic.

4) No nickel-rich iron object of the Bronze Age consists of smelted iron. We therefore may ask whether one single iron object from this time is not made of meteoritic iron, since the low level or even absence of $\mathrm{Ni}$ can no more be considered as a proof for the smelting origin of iron.

5) If our interpretation that the three iron objects from Tut's treasure are made of three different iron meteorites, is correct, this suggests an active search about iron meteorites.

\subsection{Transition artifacts}

Results are listed in OLSM table A5. Complementary information is given in the OLSM A5.1.

Le Louvre specimens. For both the halberd and the adze (Luristan, ca. 1300- 650 BCE), the Ni fall below the detection limit while $\mathrm{Co}$ is not (detection limit is $0.02 \%$ ) which indicates a Co/Ni ratio $>10$ and a Ni/Fe ratio $<0.005$. Both artifacts are without ambiguity made of terrestrial iron. Casting a bronze socket indicates that the ability at smithing was not well mastered for these objects, which may be considered as benchmarks in bloomery iron smithing.

Zhou dynasty axes. The objects from early Zhou (about 1000 BCE) were first investigated by Foshag (1950) (in Gettens et al., 1971) who detected no nickel and concluded that the iron was not meteoritic. Gettens et al. however made insightful analyses, including microprobe analyses and metallographic examinations. They showed unambiguously that both artifacts are made from meteoritic iron. What interests us more are the chemical analyses of both metal and oxidation products, which fall within the field of iron meteorites (Fig. 3 and table A4).

Neuchatel artifacts. Three needles, two nails and one hook were analyzed. Despite their chemical composition, the needle typology is identical to and typical of Bronze Age needles of that area. In other words they were probably produced in the same region, between 950 and $850 \mathrm{BCE}$ according to dendrochronological dating (Rychner 1979; Rychner-Faraggi 1993) in the Late Bronze Age of western Switzerland. Their composition is typical of smelted iron which indicates that late Bronze Age in Europe is not equivalent (technologically speaking) to Near Eastern final Bronze Age. We know that iron was smelted further east at the same time (possibly as early as 1200 BCE in SW Asia) and iron ingots may have been imported as precious metal to make jewelry.

\subsection{Iron age artifacts.}

The results are listed in the On line supplementary material; table A5.2 with complementary informations in section A4.3.

\subsubsection{Present study}

The Marsal ingots (NE France) are quite fresh. From the archaeological context they are dated at about $700 \pm 100 \mathrm{BCE}$. Their $\mathrm{Ni}$ and Co contents are exceedingly low, mostly below the detection limit of our equipment. When $\mathrm{Co}$ and $\mathrm{Ni}$ are detectable the $\mathrm{Co} / \mathrm{Ni}$ ratio is observed to exceed unity in strong contrast with meteoritic iron $(<0.2)$ and clearly outside of the trend defined by meteoritic material. In addition the amount of $\mathrm{Cu}$ is sometimes significant (up to $0.5 \%$ in one of six ingots) in contrast to the composition of meteoritic metal. The different chemical compositions among the various ingots analyzed suggest several provenances that cannot be specified for the moment. For such low $\mathrm{Ni}$ values it is more convenient to show the data in an Fe/Co vs. Ni plot with a log scale. The field for Marsal ingots falls unambiguously apart from the meteoritic compositions (Fig. 4).

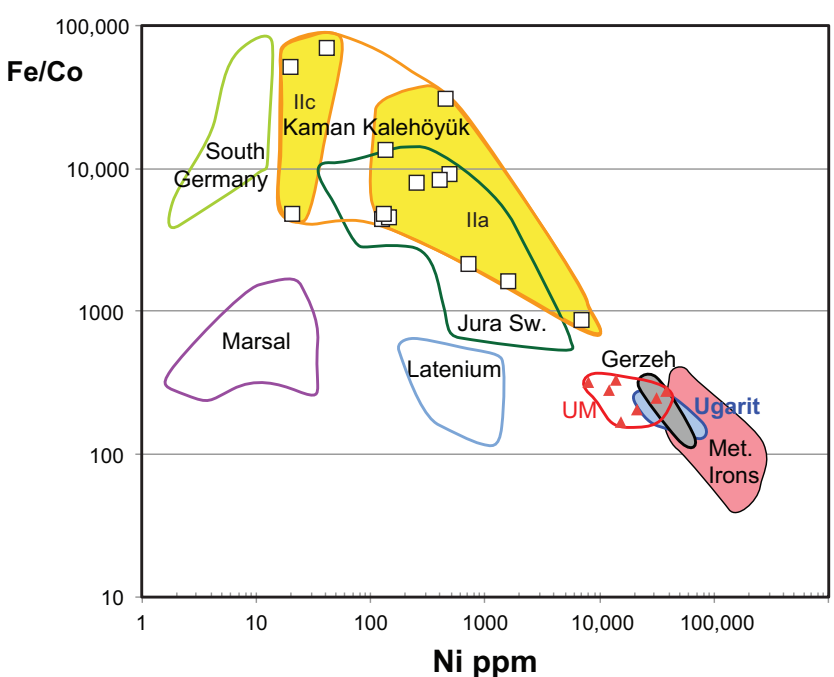

Fig. 4. Plot of Fe/Co against $\mathrm{Ni}$ for Bronze Age and Iron Age artifacts. The log scale permits to illustrate the variations for low $\mathrm{Ni}$ irons (e.g. smelted irons from sedimentary ores) and high $\mathrm{Ni}$ irons (e.g. meteoritic irons). At $1 \% \mathrm{Ni}(10,000 \mathrm{ppm})$ the Fe/Co ratio permits to distinguish samples with otherwise similar $\mathrm{Ni}$ abundance. $\mathrm{UM}=\mathrm{Umm}$ el Marra pendant (Syria) (Schwartz et al.). Latenium $=$ Neuchatel (Rychner, 1987). Jura Sw(itzerland) (Eschenlohr et al. 2007). White squares are data for Kaman KaleHöyük levels IIA and IIc (Turkey) from (Akanuma, 2006). 


\section{Irons from Poland}

Czestochowa-Rakowa bracelets are also dated from Hallstatt C (800-600 BCE). Our Ni results are in agreement with those of Kotowiecki (2004) 18.5 and $12.5 \% \mathrm{Ni}$ for $\mathrm{CrZ1}$ and $\mathrm{CrZ2}$ respectively, to be compared to our values of 15.5-18.4 and 18.1-21.2\% $\mathrm{Ni}$, an unusually high $\mathrm{Ni}$ content. Piaskowski, (1982) gives comparable results for $\mathrm{Crz} 1$ of $18.25 \% \mathrm{Ni}$, $0.58 \%$ Co and $12.4 \% \mathrm{Ni}$ for CrZ2. These compositions fall nicely in the field of iron meteorites. The suggestion of previous workers (e.g. Photos, 1989) that such high $\mathrm{Ni}$ metal could be produced from terrestrial ores is not supported in the present case by the chemical composition.

Wietrzno Axe (Hallstatt unspecified) is a special case, which illustrates the potential of the method. The data points in figure 3 plot below the field of iron meteorites despite a high $\mathrm{Ni}$ content (5.5 to $7.6 \% \mathrm{Ni}$ ) typical of iron meteorites indicating that for its $\mathrm{Ni} / \mathrm{Co}$ ratio, the $\mathrm{Ni}$ content should be higher (Fig. 3). One simple explanation is that its metal is a mixture of terrestrial iron (low $\mathrm{Co}$, low $\mathrm{Ni}$ ) with meteoritic iron similar to that used for the bracelets. Doing so the $\mathrm{Ni} / \mathrm{Co}$ ratio remains unchanged (the contribution from terrestrial iron is negligible) whereas the $\mathrm{Ni} / \mathrm{Fe}$ ratio is significantly decreased. This explanation is substantiated by the observation that the blade is made of five layers (two high in $\mathrm{Ni}$ and three devoid of $\mathrm{Ni}$; Piaskowski, 1982), which cannot be resolved with the $\mathrm{p}-\mathrm{XRF}$ analyzer. This unexpected result suggests that the similarity between meteoritic iron and smelted iron was recognized and that the use of meteoritic iron was still a viable practice. Because of the rarity of iron meteorites with such a high Ni content exceeding 15 $\%$, it is likely that the same meteorite was used for the bracelets and the axe.

\subsubsection{Literature data}

We selected examples where archaeological artifacts were analyzed for $\mathrm{Co}$ and $\mathrm{Ni}$ on sufficiently well preserved samples (some metal is preserved): Fragments from Kaman Kalehöyük (Turkey) (Akanuma, 2006), Western European irons of Manching (South Germany) (Schwab et al. 2006) and two from Renningen and one from Grösseltal (South Germany) (Brauns et al. 2013). More information can be found in the On line supplementary material; section A4.2.

The results are plotted in figure 4 . All data fields are presented in figure 4 and, as expected fall quite far from the meteoritic field.

Finally the more recent objects from DevélierCourtetelle (Jura, Switzerland), a set of 67 objects, analyzed by Eschenlohr et al., (2007) are low in $\mathrm{Ni}$ (40-4000 ppm; average $1200 \mathrm{ppm}$ ) with a Co/Ni ratio ranging 0.02 to 3 (average 0.43 ).

\subsection{Ni bearing iron ores}

We showed that smelted and meteoritic irons can be distinguished from their $\mathrm{Fe}: \mathrm{Co}: \mathrm{Ni}$ composition, still according to previous suggestions we must investigate whether lateritic iron ores which reportedly contain some nickel, could produce iron distinguishable from meteoritic iron. As noticed by Pryce and Natapintu (2009) laterites cover a wide domain of compositions, but the ones we are concerned with are those developed on peridotites. These are rocks with dominant $(>60 \%)$ olivine of formula $(\mathrm{Mg}, \mathrm{Fe})_{2} \mathrm{SiO}_{4}$. These contain significant amount of iron oxide (about $10 \%$ on the average) and little aluminum oxide (less that $3 \%$ ).

Lateritic ores: The $\mathrm{Fe}, \mathrm{Co}$ and $\mathrm{Ni}$ contents were measured across alteration profiles, from the fresh mother rocks to the iron oxide cap. The iron content increases from bottom to top, while the $\mathrm{Ni}$ first increases then decreases at the top where the iron ore is of the best quality (low silica content). The $\mathrm{Ni} / \mathrm{Fe}$ and $\mathrm{Ni} / \mathrm{Co}$ ratios vary along the profile and the observed correlation passes through the starting composition of fresh peridotite, which is also the terrestrial mantle composition (Fig. 5). In order to avoid confusion, we selected the data for potential iron ores, that is rocks with less than $20 \%$ silica and more than $50 \% \mathrm{Fe}$. The results taken from the literature are presented in figure 5 and 6 . In figure 5 , the correlation lies below the field of iron meteorites and it appears that for low $\mathrm{Ni}$ contents there might be some ambiguity between weathered meteoritic and lateritic compositions. Some of the scatter is due to the small size of analyzed samples (on the order of hundred $\mathrm{mg}$ ) and we expect that the charge of a

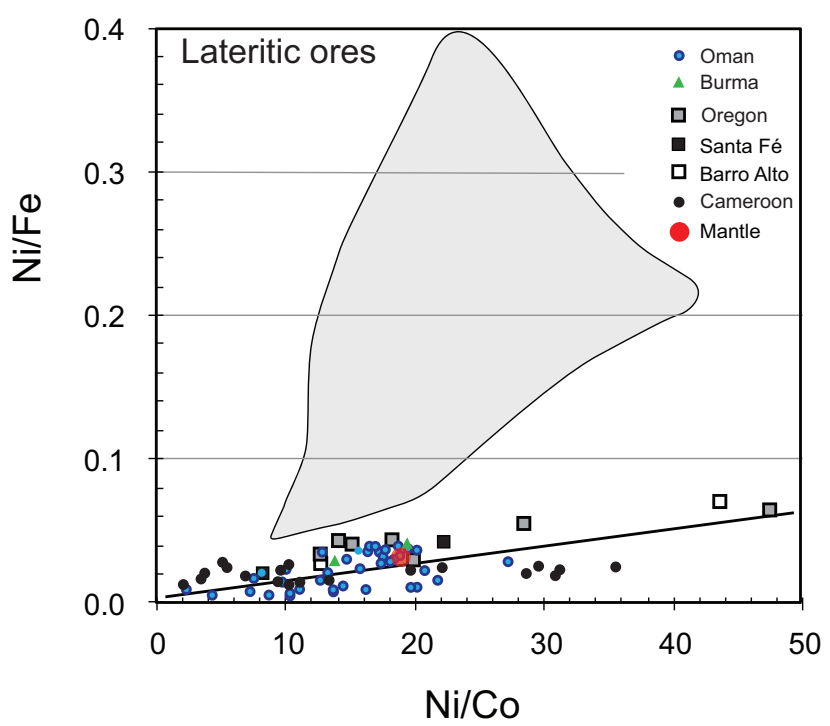

Fig. 5. Same as fig. 1 for diverse lateritic iron ores. The trend for terrestrial iron is clearly different from that of extraterrestrial material. Barro Alto and Santa Fé (Brazil) are from Trescases and Oliveira, (1981), Cameroon from Yongue-Fouateu et al., (2006), Burma from Schellmann, (1989), Oregon from Hotz, (1964) and Oman from Al Kirbash, (2015). 
Terrestrial mantle composition falls on the same trend.

smelter (several $\mathrm{kg}$ ) would exhibit less dispersion due to the averaging effect. The same is observed in figure 6. Some overlap is observed in the field representing the Umm el Marra iron pendant, which was shown to be the most weathered artifact.

More interestingly, the data for Kaman Kalehöyük, stratum II a (Fig 4-6), overlap with the lateritic field but extend to significantly lower $\mathrm{Ni}$ contents. It is well known that such lateritic ores are commonplace in Anatolia (see e.g. Pigott, 1989).

These data however are for lateritic ores not metal. There is an additional possibility, which we did not consider yet: some fractionation might occur during the reduction process, thus changing the $\mathrm{Ni} / \mathrm{Fe}$ and/or Ni/Co ratios. One obvious question then is whether some fractionation occurs between lateritic ores and the metal (Photos, 1987). This point will be discussed below.

Pyrrhotite: Some pyrrhotites (FeS) may contain significant concentrations of $\mathrm{Ni}$. This is illustrated by the composition of pyrrhotite of the Oshirabetsu Mine, Hokkaido (Bamba, 1981; On line supplementary material; table A3) ranging from 0.02 to $1.1 \% \mathrm{Ni}$. Their $\mathrm{Ni} / \mathrm{Fe}(<0.02)$ and $\mathrm{Ni} / \mathrm{Co}(0.5-39)$ plot along a trend below the terrestrial mantle correlation defined by laterites. They are significantly different from all meteoritic values and cannot explain the composition of Bronze Age irons.

\section{Discussion}

The starting point of this study was the controversy about the ultimate source of iron: meteoritic or smelted. According to previous results, the abundance of $\mathrm{Ni}$ in metal or the $\mathrm{Ni} / \mathrm{Fe}$ ratio was considered a strong indicator of the origin of iron. We

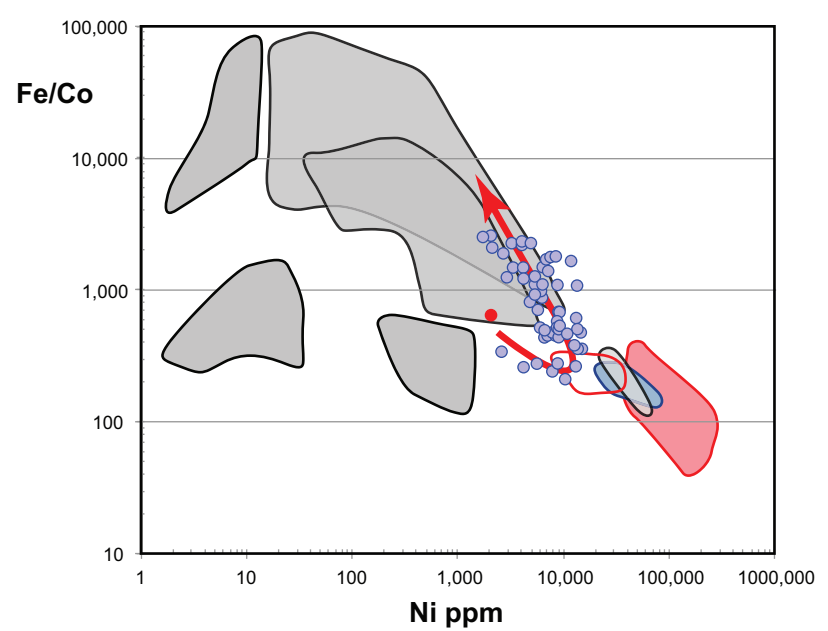

Fig. 6. Same as figure 4 for lateritic samples (dots; same set of data points as in fig. 5). Notice the weathering path (red arrow) from the mantle value (red dot) with $\mathrm{Ni}$ increasing and then decreasing; the opposite being observed for Fe/Co. The fields for iron meteorites and iron artifacts from figure 4 are shown for comparison. confirm that when the $\mathrm{Ni}$ is low, especially for weathered specimens, it is not sufficient as a criterion, whence the search for a more robust tracer of origin. According to the above results, the $\mathrm{Fe} / \mathrm{Co} / \mathrm{Ni}$ composition can provide the required information, which can be obtained using p-XRF. Analyzing several spots is highly recommended: on one single artifact, variable $\mathrm{Ni}$ is measured due to the extent of weathering, but the trend in a Ni/Fe vs $\mathrm{Ni} / \mathrm{Co}$ appears to be a robust information as it permits to distinguish terrestrial from meteoritic iron.

The effect of weathering. The above results show that weathering of meteoritic iron affects the $\mathrm{Ni}$ content and the $\mathrm{Ni} / \mathrm{Fe}$ ratio (Fig. 2-3). However, the $\mathrm{Ni} / \mathrm{Co}$ and $\mathrm{Ni} / \mathrm{Fe}$ variations still correlate. The low $\mathrm{Ni} / \mathrm{Fe}$ ratio (or the $\mathrm{Ni}$ abundance) of terrestrial irons could be similar to that of some weathered meteoritic irons but at the same time their $\mathrm{Ni} / \mathrm{Co}$ ratio does not fall on the correlation exhibited by meteoritic irons. The effect of weathering was ignored in most previous investigations but is now well established.

The effect of smelting. Photos (1989) found metal prills with comparatively high $\mathrm{Ni} / \mathrm{Fe}$ ratios in some iron slags from Petres (N. Greece). It is noteworthy that no iron artifacts with high $\mathrm{Ni}$ content were ever found in the same context. The slags in question were high in iron oxide (wüstite) and contained small amounts of metal prills. She concluded that this could explain the abundance of $\mathrm{Ni}$ in all irons from the Bronze Age without the need of the extraterrestrial iron hypothesis. I cannot share this view and claim that the high $\mathrm{Ni}$ content of iron prills in slag ensues anytime, when the ore reduction fails. $\mathrm{Ni}$ is more easily reduced than iron, therefore if the smelting conditions were slightly too oxidizing, it is quite possible that nearly all $\mathrm{Ni}$ was reduced while only a small fraction of iron was. It can be shown that the fraction of $\mathrm{Ni}$ in the metal is a measure of the oxygen partial pressure in the furnace. The observed heterogeneity of $\mathrm{Ni}$ in the iron is a good indicator of out-of-control oxidizing conditions. Then a very small quantity of metal is obtained with a high $\mathrm{Ni}$ content (tens of \%) if the starting ore contained some $\mathrm{Ni}$. This is what the experiments of Photos (1989) yielded and possibly the case in Petres discarded slag as well. Extracting metal prills from a large quantity of slag would be a very hard task for little reward and most probably therefore the slag was discarded. The recovery of metal by a second smelting operation seemed questionable from an economical point of view. For this second reduction stage to be efficient, crushing the slag to permit exchange with carbon in the furnace would be required. This operation would have been too demanding when compared with using fresh ore. The experiments of Photos confirm our view. Some of the metal prills she analyzed after her smelting experiments contain up to $67 \%$ nickel. 
When starting from an ore with $1 \% \mathrm{NiO}(0.7 \% \mathrm{Ni})$ and $72 \% \mathrm{Fe}_{2} \mathrm{O}_{3}(50 \% \mathrm{Fe}$ ), this suggests that only 0.3 $\% \mathrm{Fe}$ was reduced (for a metal with $20 \% \mathrm{Ni}, 2.8 \%$ of $\mathrm{Fe}$ ), a very poor yield! In addition the composition of chrome-spinel in the slag, indicates that $17 \%$ of its $\mathrm{Fe}$ is actually $\mathrm{Fe}^{3+}$ indicating that oxygen fugacity was close to the magnetite-wüstite buffer, that is far above the reducing conditions necessary to obtain iron metal.

Another important question is: are such Ni rich ores really common? I would say, in principle not. As already mentioned above, the best iron ores of the lateritic type contain little nickel ( see also the discussion by Pryce and Natapintu (2009) on the quality of laterite in order to be a qualified iron ore) . Those high in nickel (actually nickel ores as reported in figures 5-6) contain also quite large amounts of silica, which makes them poor iron ores; their color is orange yellowish and they look quite different from the true iron ores having a dark rusty color. This is because during the final stages of lateritization, silica and nickel $\left(\mathrm{Ni}^{2+}\right)$ are leached away, whereas $\mathrm{Fe}^{3+}$ remains immobile as iron oxides. It is important to notice that no smelted iron object of the Iron Age has been reported with significant amounts of $\mathrm{Ni}$. In particular, the irons of Kaman Kalehöyük fall in the range 0.7 to $0.01 \% \mathrm{Ni}$ (Akanuma et al. 2006), whereas numerous lateritic ores are present in Anatolia. According to their composition (Fig.4-6) we think that Kaman Kalehöyük artifacts are good candidates for iron derived from lateritic iron ores. Such irons have $\mathrm{Fe} / \mathrm{Co}$ higher than meteoritic irons and also higher than the lowest Fe/Co ratio of nickel rich ores, but the overlap is significant.

\section{Conclusions}

We conclude that it appears now important to measure correctly Bronze Age irons for their $\mathrm{Fe}: \mathrm{Co}: \mathrm{Ni}$ abundances, in order to determine whether or not, any specimen from that time is made from terrestrial iron. Replicate analyses are necessary since weathering leads to variably depleted $\mathrm{Ni}$ contents and a Ni content below $1 \%$ alone is no proof of origin; for $\mathrm{Ni}$ in excess of $1 \%$ the $\mathrm{Ni}: \mathrm{Co}: \mathrm{Fe}$ correlation will be conclusive. Scraps of rust are strongly biased samples, depleted in $\mathrm{Ni}$ and should be avoided, whereas oxidized artifacts are acceptable.

The present results complementing high quality analyzes from the literature suggest that (most or) all irons from the Bronze Age are derived from meteoritic iron, until some transition period, which occurred supposedly close to about 1200 BC. The next step will be to determine where and when terrestrial iron smelting appeared for the first time.

Acknowledgements: The author is indebted to $\mathrm{P}$. Rochette for providing the Fe: Ni reference alloys. M. Fialin helped with EMP analyses. B. Zanda kindly provided the MNHN specimens. This work would not have been possible without the enthusiastic support of a number of archaeologist colleagues and curators. Musée du Louvre, in Paris ( $F$. Bridey), Musée du Laténium in Neuchatel (D. Ramseyer), Musée National d'archéologie in St Germain en Laye (L. Olivier), National archaeology Museum in Aleppo (G. Schwartz, V. Matoian, A. Bilal and B. Jamouss); Petrie Museum, (S. Pancaldo) and UCL (Th. Rehren). M. Martinon-Torres (UCL) provided a bloomery iron sample from Gresham shipwreck. K. Mazurek permitted the analyses of the polished sections of Polish artifacts. A. Hmani provided a bloomery iron from Morocco. M. Hmani allowed the p-XRF measurements of a collection of iron meteorites. A. Muszynski (Poznan University) gave access to a collection of Morasko irons and provided a reference sample. R. Hewins patiently corrected my English. This research did not receive any specific grant from funding agencies in the public, commercial, or not-for-profit sectors.

\section{References}

Akanuma, H., 2006. Changes in Iron Use during the 2nd and 1st Millennia B.C. at Kaman-Kalehöyük, Turkey: Composition of Iron Artifacts from Stratum III and Stratum II. Anatolian Archaeological Studies 15, 207-222.

Al Kirbash, S.A., 2016. Geology, mineralogy, and geochemistry of low grade Ni-lateritic soil (Oman Mountains, Oman). Chemie der Erde. 76, 363381

Auer, J., and Firth A., 2007. The « Gresham Ship »: an interim report on a 16th-century wreck from Princes Channel, Thames estuary. Post-Medieval Archaeology 41/2, 222-241.

Bamba, T., 1985. Nickeliferous Pyrrhotite Deposits and Ores from the Oshirabetsu Mine, Tokachi Province, Hokkaido. Journal of the Faculty of Science, Hokkaido University Series 4, Geology and Mineralogy, 19, 415-438.

Ben-Yosef E., Shaar R., Tauxe L. and Ron H. (2012), A New Chronological Framework for Iron Age Copper Production at Timna (Israel) Bulletin of the American Schools of Oriental Research 367, 3171.

Bertaux, J-P., 1990 "La Lorraine antique. Villes et villages" Metz, DRAC de Lorraine, 123-124.

Bjorkman J.K. (1973) Meteors and meteorites in the ancient Near East. Meteoritics 8, 91-132.

Brauns, M., Schwab, R., Gassmann, G., Wieland, G., Pernicka, E., 2013. Provenance of Iron Age iron in southern Germany: a new approach. Journal of Archaeological Science 40, 841-849.

Buchwald, V.F., 1975. Handbook of Iron Meteorites. University of California Press, Berkeley.

Buchwald, V. F. 2005. Iron and Steel in Ancient Times. Copenhagen: Det Kongelige Danske 
Veidenskabernes Selskab. -

Comelli, D., D'Orazio M., Folco L., El-Halwagy M., Frizzi T., Alberti R., Capogrosso V., El-Naggar A., Hassan H., Nevin A., Porcelli F., Rashed M.G., and Valentini G., 2016. The meteoritic origin of Tutankhamen's iron dagger blade. Meteoritics \& Planetary Science 1-9. doi: 10.1111/maps.12664

Craddock, P., 1995. Early Metal Mining and Production Edinburgh University Press 363 p.

Desch, C., 1929. Reports on the Metallurgical Examination of Specimens for the

Sumerian Committee of the British Association. Reports of the British Association for the Advancements of Science.

El Gayar, E.S., 1995. Pre-dynastic iron beads from Gerzeh, Egypt. iams newsletter 19, 11-12.

Eschenlohr, L., Friedli, V., Robert-Charrue Linder, C. and Senn, M., 2007. Develier- Courtételle un Habitat Rural Mérovingien. 2. Métallurgie du fer et mobilier métallique. Cahier d'Archéologie Jurassienne 14, 170-188.

Gale N. H., Bachmann H.-G., Rothenberg B., StosGale Z. A. and Tylecote R.F., 1990, The Adventitious Production of Iron in the Smelting of Copper, in B. Rothenberg (ed), The Ancient Metallurgy of Copper (London), 182-91.

Gattacceca, J., Eisenlohr P., and Rochette P. 2004. Calibration of in situ magnetic susceptibility measurements. Geophysical Journal International 158, 42-49.

Gettens, R.J., Clarke, R. S., Jr., Chase, W.T.,1971. Two early Chinese Bronze Weapons with Meteoritic Iron Blades. Occasional Papers 4, 1-77, Freer Gallery of Art Washington, D.C.

Götze, A., 1902. In Troja und Ilion (W. Dorpfeld). Athens: Beck and Barth, p. 423.

Gowland, H., Bannister, C., 1927. Ancient Egyptian Metallurgy (London). Guide to

the Expression of Uncertainty in Measurement. ISO, Geneva, 1993.

Helmi, F.M. and Barakat, K., 1995. Microanalysis of Tutankhamen's Dagger. Proc. of the 1st Int. Conf. on ancient Egyptian Mining and Metallurgy and Conservation of metallic artifacts. 287-288.

Hotz, P.E., 1967. Nickeliferous Laterites in Southwestern Oregon and Northwestern California. Economic Geology, 59, 355-396.

Jambon, A., 2010. Report on Analyses Performed at the Petrie Museum. UCL. Report, filed at the UCL Petrie Museum of Egyptian Archaeology.

Jambon, A., Chanut C., Matoian V., 2017. La hache extra-terrestre d'Ougarit (Syrie). Etudes ougaritiques.

Jambon, A. 2017, A Meteoritic Iron Pendant from Umm el Marra tomb I. Excavations at Umm elMarra: The Third Millennium BC Occupation. I. Schwartz, Glenn M. (editor) In preparation, Cotsen Institute of Archaeology Press, University of California at Los Angeles.
Jean, E., 2001. Le fer chez les Hittites : un Bilan des Données Archéologiques, in Aux origines de la métallurgie du fer. Mediterranean Archaeology 14, 163-188

Johnson, D., Tyldesley, J., Lowe, T., Withers P. J., and Grady M.M., 2013. Analysis of a prehistoric Egyptian iron bead with implications for the use and perception of meteorite iron in ancient Egypt. Meteoritics and Planetary Science, 48, 997-1006.

Kosay, H.Z., 1951. Les fouilles d'Alaca Höyük. Ankara.

Kotowiecki, A., 2004. Artifacts in Polish collections made of meteoritic iron. Meteoritics and Planetary Science 39, Supplement, A151-A156.

Li Chung, 1979. Studies on the Iron Blade of a Shang Dynasty Bronze "Yüeh-Axe" Unearthed at KaoCh'eng,Hopei, China. Ars Orientalis 11, 259-289

McDonough, W.F., and Sun, S.-S.,1995. Composition of the Earth. Chemical Geology 120: 223-253. doi: 10.1016/0009-2541(94)00140-4.

Merkel, JF; Barrett, B; (2000) The adventitious production of iron in the smelting of copper revisited: metallographic evidence against a tempting model. Historical Metallurgy 34 (2):5966.

Meteoritic Bulletin database (http://www.Ipi.usra.edu/meteor/)

Mittlefehldt, D.W., Mc Coy, T.J., Goodrich C.A. and Kracher, A., 1998. Non-Chondritic Meteorites from asteroidal Bodies, in Reviews in Mineralogy 36 , chap. 4.

Nakai, I., Abe, Y., Tantrakarn, K., Omura, S., and Erkut, S., 2008. Preliminary report on the Analysis of an Early Bronze Age iron dagger excavated from Alacahöyük. Anatolian Archaeological Studies 17, 321-324.

Overlaet, B., 2004. Luristan metalwork in the Iron Age. In: Stöllner T, Slotta R, Vatandoust A, editors. Persia's ancient splendour, mining, handicraft and archaeology, Deutsches Bergbau-Museum, Bochum. 2004. p. 328-38.

Petrie, W.M.F., Wainwright, G.A., Mackay, E., 1912. The Labyrinth, Gerzeh and

Mazghuneh, vol. XXI. British School of Archaeology in Egypt, London.

Photos, E. 1987. Early Extractive Iron Metallurgy in N Greece: a unified approach to regional archaeometallurgy. Ph. D. Thesis University of London, p349.

Photos, E., 1989. The question of meteoritic versus smelted nickel-rich iron: archaeological evidence and experimental results. World Archaeology 20, 403-421.

Piaskowski, J., 1960. An interesting example of early technology: a socketed axe from Wiertrzno-Botkra in the Carpathians. Journal of the Iron and Steel Institute 194(3): 336-8.

Piaskowski, J., 1982. A study of the origin of the ancient high $\mathrm{Ni}$ iron generally regarded as 
meteoritic. In Early Pyrotechnology (eds. T. A. Wertime and S. F. Wertime). Washington DC: Smithsonian Institution, pp. 237-243.

Pigott V. C. 1989. The Emergence of Iron Use at Hasanlu. Expedition 32: 67-79

Pilski, A. S., Wasson J.T., A. Muszynski, A., Kryza R., Karwowski Ł., and Nowak M., 2013. Low-Ir IAB irons from Morasko and other locations in central Europe: One fall, possibly distinct from IAB-MG. Meteoritics \& Planetary Science 48, 2531-2541. doi:10.1111/maps. 12225

Pryce T.O. and Natapintu S., 2009 Smelting iron from laterite: Technical Possibility or Ethnographic Aberration? Asian Perspectives, 48, 249-264.

Rehren, Th., Belgya, T., Jambon, A., Káli, G., Kasztovszky, Z., Kis, Z., Kovács, I., Maróti, B., Martinón-Torres, M., Miniaci, G., Pigott, V.C., Radivojevič, M., Rosta, L., Szentmiklósi, L., Sökefalvi-Nagy, Z., 2013. 5,000 years old Egyptian iron beads made from hammered meteoritic iron. J. of Archaeological Science, 40, 4785-4792. doi:10.1016/j.jas.2013.06.002

Rochette, P., Gattacceca J., Bourot-Denise M., Consolmagno, G.J., Folco L., Kohout T., Pesonen L., Sagnotti L., 2009. Magnetic classification of stony meteorites: 3. Achondrites. Meteoritics \& Planet. Sci., 44, 405-428.

Rothenberg B., 1988, The Egyptian Mining Temple at Timna (London). Researches in the Arabah 19591984 1; Metal in History 2. London: Institute for Archaeo-Metallurgical Studies.

Rychner, V. 1979. L'âge du Bronze final à Auvernier (lac de Neuchâtel, Suisse). Typologie et chronologie des anciennes collections conservées en Suisse. T.1 et 2. Cahiers d'Archéologie Romande, 15-16), Lausanne.

Rychner, V. 1987. Auvernier 1968-1975. Le mobilier métallique du bronze final. Formes et techniques. Cahiers d'Archéologie Romande, 37, Lausanne.

Rychner-Faraggi, A.-M. 1993. HauteriveChampréveyres, 9. Métal et parures au Bronze final. Archéologie neuchâteloise 17, Neuchâtel.

Schaeffer, C. F.-A., 1939. Une hache d'armes Mitanienne de Ras Shamra. Ugaritica 3, 107-125.

Schellmann, W., 1989. Composition and origin of lateritic nickel ore at Tagaung Taung, Burma
Mineral. Deposita 24, 161-168.

Schwab, R., Heger, D., Höppner, B., Pernicka, E., 2006. The Provenance of Iron Artefacts from Manching: A multi-technique Approach. Archaeometry 48, 431-450.

Schwartz, G.M., Curvers, H.H., Dunham, S., Stuart, B., 2003. A Third-Millennium B.C. Elite Tomb and Other New Evidence from Tell Umm el-Marra, Syria. American Journal of Archaeology 107, 325-361.

Ströbele, F., Broschat, K. Koeberl, C., Zipfel, J. Hassan, H., Eckmann, Ch. 2016. The Iron Objects of Tutanchamun. Metalla, Sonderheft 8, 186-189. Archäometrie und Denkmalpflege 2016, Göttingen.

Trescases, J.J., Oliveira, S.M.B. de, 1981. A jazida de niquel de Barro Alto. Ata I Simp. Geol. CentroOeste, Goiania, 519-538.

Wainwright, G. A., 1912. Pre-dynastic iron beads in Egypt. Revue Archéologique 19, 255-259.

Wainwright, G.A., 1932. Iron in Egypt. Journal of Egyptian Archaeology 18, 3-15.

Waldbaum, J., 1980. The First Archaeological Appearance of Iron and the Transition to the Iron Age. Pp. 69-98 in The Coming of the Age of Iron, eds. T. A. Wertime and D. Muhly. New Haven and London: Yale University Press.

Waldbaum, J.C., 1999. The coming of Iron in the Eastern Mediterranean: Thirty years of Archaeological and Technological Research in The Archaeometallurgy of the Asian World, V.C. Pigott ed. MASCA Research Papers in Science and Archaeology 16. 27-57.

Wertime, T.A., 1973. The Beginnings of Metallurgy in Anatolia. Anatolian Studies 49, 177-187.

Yalçın, Ü., 1999. Early Iron Metallurgy in Anatolia. Anatolian Studies 49, 177-187.

Yongue-Fouateu, R., Ghogomu R.T., Penaye J., Ekodeck G.E., Stendal H., Colin F. 2006, Nickel and cobalt distribution in the laterites of the Lomié region, south-east Cameroon. Journal of African Earth Sciences 45, 33-47

Zimny, J., 1965. Metaloznawcze badania halsztackich wyrobow zelaznych z CzestochowyRakowa. Rocznik Muzeum w Czestochowie 1, 329-400. In Polish. 


\section{On Line Supplementary material}

A1. Meteoritic vs. Terrestrial Iron: a controversy. From the beginning of the twentieth century, starting with Dörpfeld's report in 1902 of nickel-rich iron in a mace head at Troy, and followed shortly by the find of iron beads in two tombs from the early Bronze Age at Gerzeh, (Egypt) in 1911, it was suggested that the iron was extraterrestrial as the metal contained a significant amount of nickel $(\mathrm{Ni})$, the signature of meteoritic iron (e.g. Götze, 1902; Petrie et al.1912; Desch, 1929; Bjorkman, 1973). This disturbing idea was challenged very early, on the basis of two strong arguments: a number of irons contained too low amounts of $\mathrm{Ni}$ compared to meteoritic metal, and some iron ores were shown to contain significant amounts of Ni. Conversely, a number of iron artifacts from the Bronze Age contain some Ni whereas none from the Iron Age are reported as Ni-bearing (in excess of $1 \%$ ) except for particular instances where it was shown that the ultimate iron source was meteoritic (e.g. tools from Greenland, Buchwald, $1975,2005)$. In a number of instances, duplicate analyses proved to be contradictory. For instance the $\mathrm{Ni}$ content analyzed in Gerzeh beads was found negligible by Gowland and Bannister (1927) and EI Gayar (1995), in contradiction with the results of Desch (1929), Wainwright (1932), Johnson et al. (2013) and Rehren et al. (2013). In order to be as little invasive as possible, surface chips or scraps were sometimes retrieved for analytical purpose, with the consequence that significantly weathered material was analyzed, which as we now know could have lost most of its Ni (Li Chung 1979; Craddock, 1995). Photos (1989) reported on archaeological slags containing Ni-rich metal prills, from Petres (N-E Greece) providing support to the idea of $\mathrm{Ni}$ bearing terrestrial iron but unfortunately no iron object with such a composition was ever found. The experimental production of $\mathrm{Ni}$ rich metal seemed to support this argument. As a consequence of these contradictory observations, some confusion followed: a number of authors decided that, to be considered extraterrestrial, the metal should contain more than a minimal amount of $\mathrm{Ni}$ (e.g. $5 \%$ ) otherwise it would be considered as terrestrial (see e.g. Waldbaum 19801999; Photos, 1989; Yalcin 1999; Merkel and Barrett, 2000), which we consider as a totally irrational conclusion: the analytical results of Gowland and Bannister (1927) and El Gayar (1995) already mentioned, show that meteoritic iron, when corroded, can be totally deprived from its original $\mathrm{Ni}$ (see also Craddock 1995). Tutankhamen's dagger as analyzed by Helmi and Barakat (1995), with 2.8\% Nickel was considered terrestrial while the more recent analyses of Comelli et al. (2016) and Ströbele et al. (2016) with 10.8 and $12.9 \%$ Ni respectively show that it is undoubtedly meteoritic. We conclude that analytical difficulties are a serious possibility and interpretation of the analytical results must be reconsidered. We must admit however that most of the time, conclusive arguments are missing partly because a metallurgical study, which could prove an extraterrestrial origin, is missing, since a fresh sample cannot be taken for analysis.

Another difficulty is in dating archaeological artifacts. Some irons, reputedly from the Bronze age, are actually more recent. A good example is provided by the irons of Timna (Gale et al. 1990), which were dated from the 14th-12th century BCE (Rothenberg, 1988). More recent dating indicates that they are Iron Age (Ben Yosef et al. 2012).

\section{An how to overcome it...}

Recent analytical improvements permit non-invasive textural studies (see e.g. Johnson et al. 2013; Rehren et al. 2013) and provide an unambiguous answer but the analytical procedures are arduous and require the transfer of the artifacts to an analytical facility, which is time and money consuming and not always safe for fragile artifacts. The recent development of portable XRF equipment ( $p$-XRF) permits performing non-destructive, on-site chemical analyses, which are of particular interest whenever the chemical analyses permit the discrimination between the two types of iron (see e.g. Nakai et al., 2008). More generally, the trace element abundances in meteoritic iron are expected to differ significantly from iron derived from iron ore and this offers a powerful tool, provided that the artifacts are not pervasively weathered. The p-XRF analysis is quite efficient but the analysis of a weathered surface limits the interpretation as far as trace elements are concerned. In this paper we develop a strategy illustrated on a few examples, which permits the recognition of extraterrestrial iron conclusively, whenever the $\mathrm{Ni}$ content exceeds $1 \mathrm{wt}$. \%. We analyzed meteoritic samples, Bronze Age iron artifacts some of which have been proved to be meteoritic, Iron Age artifacts and considered literature data for additional artifacts and for $\mathrm{Ni}$ bearing ores. Critical comparison of the different data sets permits us to clearly establish a distinction between the two possible iron sources.

\section{A2. Analytical methods \\ A2.1. P-XRF}

For all artifacts we used a p-XRF analyzer (Niton X3t 900 ) using a source operated at $50 \mathrm{kV}$. A set of filters operated sequentially permits us to explore four windows in the spectrum from $1.25 \mathrm{keV}(\mathrm{Mg}, \mathrm{K}$ line) to $13.6 \mathrm{keV}(\mathrm{U}, \mathrm{K}$ line). In the present case only two were used in order to analyze light elements (from Al to $\mathrm{Ca}$ ) and transition elements from $\mathrm{Ti}$ to $\mathrm{Cu}$ (mostly). Analyses were performed in ambient air for two minutes which for transition elements is acceptable as long as the analyzer is in close contact with the surface to be analyzed, the surface is smooth and elements exhibit X-ray lines close to one another, 
which is the case for Fe, Co and Ni. Notice that under these conditions, elements lighter than $\mathrm{Al}$ could not be analyzed (e.g. oxygen), even though we obtain a different result for a metal and its oxide. The counting duration of $2 \mathrm{~min}$. was selected as the best compromise in order to decrease the limit of detection for trace elements and permit a number of replicate analyses within a reasonable time. The analyzer was calibrated using synthetic references (Fe: Ni alloys containing 100: 90: 83: 70 wt.\% Fe) and polished iron meteorites of known compositions. A special investigation on Morasko (IAB iron meteorite) permitted us to evaluate the reproducibility in analyzing natural fresh samples and accuracy by comparison with NAA (neutron activation analysis) (Pilski et al. 2013). We were particularly concerned by Co analysis. The resolution of the EDS (Energy Dispersive Spectrometer) is $0.180 \mathrm{keV}$ at $5.9 \mathrm{keV}$ (Mn K line). Co $\mathrm{K} \alpha$ line $(6.92 \mathrm{keV})$ and $\mathrm{Fe} \mathrm{K} \beta$ line (7.07 keV) on the one hand and $\mathrm{Co} K \beta$ line (7.65 $\mathrm{keV})$ and $\mathrm{Ni} \mathrm{K \alpha}$ line (7.47 keV) on the other interfere with one another, which is a significant difficulty when the abundance of $\mathrm{Co}$ is low compared to both $\mathrm{Fe}$ and $\mathrm{Ni}$, as is the case in meteorites with $\mathrm{Fe}: \mathrm{Co}: \mathrm{Ni}$ mass fractions of $90: 0.5: 8$ on average. Obtaining the correct value for $\mathrm{Co}$ requires subtraction of $\mathrm{Ni}$ and $\mathrm{Fe}$ contributions from the whole spectrum, with a routine integrated in the analyzer software. The results compared to reference samples of known composition indicate that the precision on Co under these conditions is on the order of 300 ppm, i.e. $6 \%$ relative. The subtraction of $\mathrm{Fe}$ and $\mathrm{Ni}$ peaks from the whole spectrum gives an idea of the effectiveness of the procedure (Fig. A1). The reference Fe-Ni alloys $(0,9.6,17.6$ and $30.1 \% \mathrm{Ni}$ ) are Co free (below detection level) as checked with EMPA analysis. Their spectra permit to obtain the Co-free, $\mathrm{Fe}$ and $\mathrm{Ni}$ peaks used to compute the results presented in figure $A 1$.

\section{A2.2. Electron microprobe analyses.}

In order to check for the composition of meteorite specimens, polished sections of iron meteorites: Cape of Good Hope, Coahuila, Copiapo, Juromenha were provided by MNHN Paris and analyzed with an Electron microprobe, CAMECA SX-100 equipped with four WDS spectrometers, at UPMC in Paris. The analytical conditions were: $15 \mathrm{kV}$ accelerating voltage, $10 \mathrm{nA}$ beam current for $\mathrm{Fe}$ and $\mathrm{Ni}$ and 300 $\mathrm{nA}$ for Co, focused beam, counting time $10 \mathrm{~s}$ at peak position and $10 \mathrm{~s}$ for background. The reference Fe$\mathrm{Ni}$ alloys $(0,9.6,17.6$ and $30.1 \% \mathrm{Ni})$ were analyzed for calibration of $\mathrm{Fe}$ and $\mathrm{Ni}$ and also to check the $\mathrm{p}$ $\mathrm{XRF}$ Co concentrations. Under these conditions, the detection limits are $0.1 \%(\mathrm{Fe}), 0.14 \%(\mathrm{Ni})$ and 30 ppm (Co). The $2 \sigma$ error on Co is 20 ppm.

\section{A3. Samples:}

In this paper we investigate the different chemical characteristics of meteoritic and smelted irons. This is not as trivial as it seems because of the effects of weathering. Archaeological artifacts are quite often severely corroded and their chemical composition
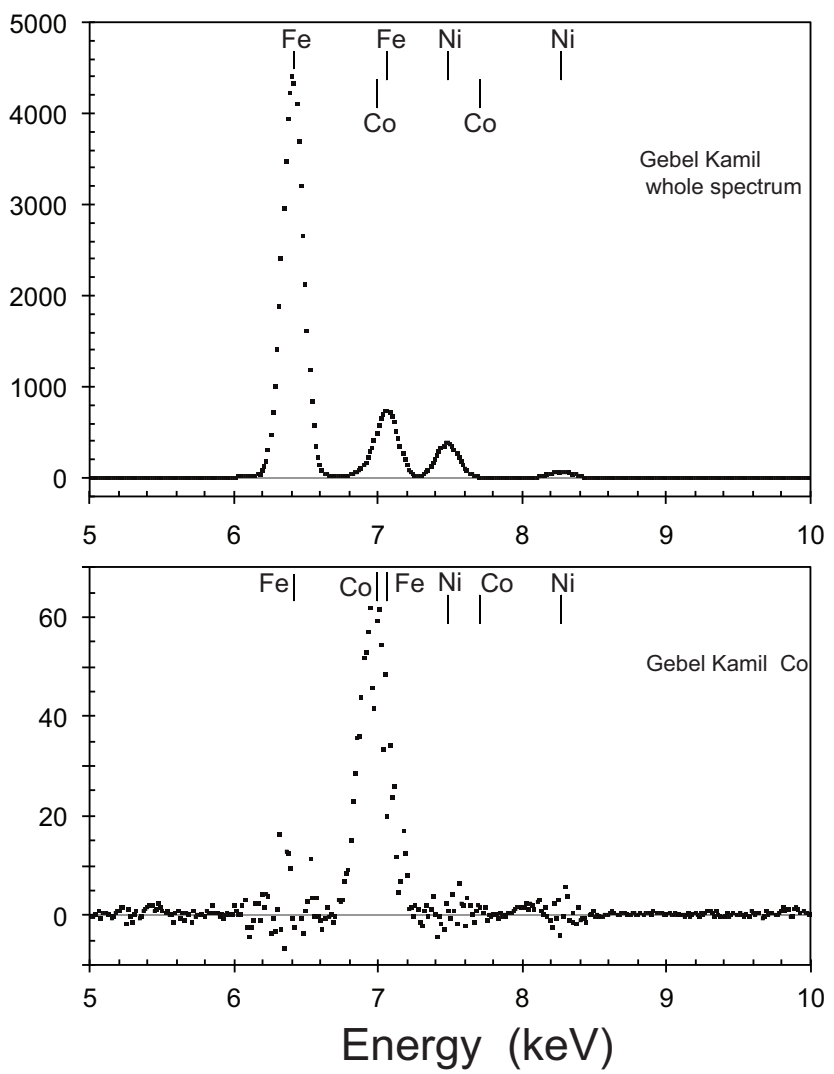

Figure A1. p-XRF spectra for Gebel Kamil iron meteorite. Top: whole spectrum. Bottom: same spectrum after subtraction of iron and nickel peaks (notice the different scales). The Co peak (Ko line) is clearly observed, affected by a significant background noise due to the presence of abundant $\mathrm{Fe}$ and $\mathrm{Ni}$. The $\mathrm{K} \beta$ line of $\mathrm{Co}(7.65 \mathrm{keV})$ is negligible due to absorption by $\mathrm{Fe}$ (K edge at $7.11 \mathrm{keV}$ ).

weathering. Archaeological artifacts are quite often severely corroded and their chemical composition may be affected especially at their surface. It is of utmost importance to assess the difference between weathered meteoritic iron, depleted in $\mathrm{Ni}$, and smelted iron with low $\mathrm{Ni}$ content on samples of welldefined origin, terrestrial and meteoritic, from the Bronze and Iron Age.

\section{A3.1. Synthetic reference samples (Table}

A1)

As already mentioned, such samples were necessary to check that the analytical procedures are correct, especially the analysis of Co. A set of synthetic $\mathrm{Fe}: \mathrm{Ni}$ alloys in the range 100:0 to 70:30 free of Co and any other contaminants were analyzed several times to check for the accuracy of the p-XRF analyzer. It was important to consider reference samples without Co because of possible interference between $\mathrm{Co}, \mathrm{Ni}$ and Fe peaks. We analyzed the same polished samples with our $\mathrm{p}-\mathrm{XRF}$ and also using EMPA. 


\section{A3.2. Iron meteorites. (Table A1)}

In order to validate the comparison between artifacts and extraterrestrial irons we analyzed 15 different iron meteorites of various types with $\mathrm{p}$-XRF. Agoudal, Campo del Cielo, Canyon Diablo, Cape of Good Hope, Chinga, Copiapo, Gebel Kamil, Juromenha, Morasko, Mundrabilla, Northwest Africa (NWA) 854 (Ziz), NWA 859 (Taza), NWA 5549, Sikhote Alin, and UAI an Algerian unnamed iron ataxite. Samples were from Museum National d'Histoire Naturelle (MNHN) Paris, Moroccan Import (Asnières), Poznan University for Morasko or the private collection of the author. The overall $\mathrm{Ni}$ contents of polished samples range from 5 to $24 \%$ in agreement with literature values. For most samples, we analyzed both a fresh polished surface and the outer oxidized, more or less weathered surface. At the university of Poznan we had access to about thirty different pieces of Morasko on which we performed 31 analyses of the metal fraction. This permitted us to assess the internal variability of about $10 \%$ for $\mathrm{Co}$ and $\mathrm{Ni}$, and the different compositions of fresh and weathered surfaces. The Morasko fall date is about 5000 years B.P and the finds of the different pieces are between 1914 and the present, which gives an idea of the time during which the buried samples were subject to terrestrial weathering. The pieces analyzed however had had their surface layers, mixtures of clay and iron oxide cleaned off. In addition the results obtained on freshly polished surfaces (26 measurements) permitted us to calculate an average composition in agreement with that reported in the literature within $10 \%$ (Pilski et al. 2013).

artifacts.

\section{A3.3. Bronze Age archaeological}

For the purpose of this study we considered a set of high quality analyses from the literature, which we complemented with our own p-XRF analyses.

We selected a set of accessible objects from various Bronze Age levels. 1) Gerzeh (Egypt) beads from the Petrie Museum (UCL, London) (Wainwright 1912) studied recently using various methods, dated at 3200 BCE and shown to be meteoritic: see Rehren et al. (2013); ref numbers UC10738, UC 10739, UC10740. Actually our p-XRF measurements of the UCL beads (Jambon, 2010), motivated the more indepth studies mentioned above. 2) Umm el Marra (Syria) pendant from a tomb dated at 2300 BCE (Schwartz et al. 2003; Jambon 2017 ), in Aleppo Archaeological Museum and suggested to be meteoritic (ref. number M00299). 3) Ugarit (Ras Shamra, Syria; 1400 BCE) axe (Schaeffer, 1939; Jambon et al. 2017)) in Aleppo Archaeological Museum (ref. number RS9-250).

Additional artifacts will be considered in the discussion: one gold-handled dagger from Alaca
Höyük (Çorum, Turkey; Ankara Museum ref. number Al. K. 14) ca. 2400-2300 B.C., (Nakai et al. 2008; Kosay, 1951; Wertime, 1973), Tutankhamen's dagger $14^{\text {th }}$ century B.C. (Cairo Museum. Carter ref. 256K JE 61585), analyzed recently (Comelli et al. 2016; Ströbele, 2016), one axe from Shang dynasty, (Kao Ch'eng, Hubei, China) ca. 1400 B.C., analyzed by Li Chung (1979).

\section{A3.4. Bronze to Iron Age transition}

Two objects curated at Le Louvre Museum (Paris, France), one halberd axe (AO22953) and one adze (AO20882/AO20159) both with an iron blade and a bronze socket and reported from Luristan, were analyzed. According to their typology these two objects are considered to be quite primitive and Overlaet (2008) indicates « the characteristic Luristan style objects all belong to the Iron Age (ca. 1300-650 BCE) ». Those analyzed here with a bronze socket appear rather primitive, technically speaking.

Seven objects were analyzed at Latenium Museum in Neuchatel (Switzerland): three pins ( AUV-2242; HR93 and HR-110), one fish hook (AUV-2290), one nail (AUV-2736), one nail head (AUV-2740) and one adze $(\mathrm{N}-1)$. The objects are from lake sediments near Neuchâtel, Auvernier site (AUV) and Hauterive site $(\mathrm{H})$, and dated by dendrochronology, the pins having a well-characterized Late Bronze Age typology. According to their stratigraphic age (Rychner, 1987) they are from the Bronze Age, meaning European Bronze Age. They are contemporaneous to Iron Age objects from the Near East and for this reason we decided to consider their age in this work, to be transitional. In addition the adze $(\mathrm{N})$ is from an unspecified location in Norway.

Iron axes from early Zhou dynasty about 1000 B.C. (Hunan, China) (possibly Shang-Zhou transition period), reportedly meteoritic, were also considered (Gettens et al. 1971). According to the technical evolution in China these axes are dated from before the knowledge of iron smelting in China, but as already mentioned the iron could have been imported from the west where iron smelting was already mastered. As for the Latenium samples, we considered these axes to be transitional, just to avoid confusion.

\section{A3.5. Archaeological irons from the Iron}

Age.

We know that the beginning of the Iron Age becomes younger when going westwards from the Middle East, but also eastward (e.g. China and India) and southward (Egypt and Africa) from what appears to be a crucial area. Therefore iron objects from the Bronze Age in western European countries may be imported irons from the Iron Age in more eastern countries. We considered in this section iron artifacts from Iron Age layers. As for artifacts from the Bronze Age, we considered high quality analyses from the 
literature as well as a few analyses of our own, using our p-XRF analyzer.

Six ingots from Marsal (Moselle, France), well preserved bi-piramidal iron bars (Bertaux, 1990; L. Olivier pers. com. 2016), were analyzed at the Musée d'Archéologie Nationale in St Germain-en-Laye (France). According to the archaeological context they are dated at ca. $700 \pm 100$ BCE. A summary of the results is reported in table A3.

One oven bottom from Morocco of unspecified age (provided by A. Hmani). Bloomery iron recovered from Gresham shipwreck was kindly provided by $M$. Martinon-Torres (UCL) (wreck after 1574; excavation 2003) Auer and Firth (2007) . In addition we analyzed three artifacts from Hallstatt time, as polished sections at the University of Poznan (Poland): Two bracelets (Zimny J., 1965) from Czestochowa-Rakowa (Poland) already studied by Kotowiecki (2004) and Piaskowki (1982) and shown to have a high $\mathrm{Ni}$ content and one axe from Wietrzno (Podkarpackie Province, Poland; Hallstatt, unspecified) already mentionned by Piaskowki (1960) to be a composite made of 5 slices ( 2 and 3 of two different kinds).

In addition we collected data from the literature. Artifacts from the Iron Age excavated at Kaman Kalehöyük (Kaman, Turkey) (Akanuma, 2006) provide good examples of smelted iron in regions where $\mathrm{Ni}$ rich iron ores are available. Eschenlohr et al. (2007) analyzed a great number of irons from Develier -Courtételle (Jura, Switzerland), Brauns et al. (2013) one ingot from Renningen and one bloomery iron from Grösseltal (Baden-Württemberg, Germany) dated from late Hallstatt to early La Tène and Schwab et al. (2006) irons from Manching (Bavaria, Germany) dated from La Tène.

\section{A3.6. Iron ores.}

There exist a number of different types of iron ores. Sedimentary ores contain negligible amounts of $\mathrm{Ni}$ and Co (see e.g. Schwab et al. 2006) and are not relevant for the present study. The ultimate source of $\mathrm{Ni}$ in the Earth is the terrestrial mantle. which is composed of peridotite, a rock group with dominant olivine with about $0.3 \% \mathrm{Ni}$. Peridotite crop out in orogenic massifs forming the substratum of former oceanic crust now included in orogenic belts. $\mathrm{Ni}$ and Co are contained mostly in olivine and their concentrations in peridotites are marginally variable. The average composition of the mantle has been estimated by a number of workers considering a significant database (see e.g. McDonough and Sun, 1995). Weathered peridotites are transformed to laterites which ultimately become highly concentrated in iron and are potential ores. Lateritic iron ores are considered here for two reasons: (1) they may contain variable but significant amounts of $\mathrm{Ni}$ and $\mathrm{Co}$. (2) Such ores are quite common in the Near East for instance in Greece, Anatolia, Cyprus and Iran. The compositions of such ores are available in the literature. We selected data obtained at various levels in alteration profiles (ore beds) with a significant amount of iron oxide in order to document varied $\mathrm{Fe} / \mathrm{Ni}$ ratios corresponding to different levels in the alteration profile from Oman (Al Kirbash, 2016), Barro alto and Santa Fé, Brazil (Trescases and Oliveira,1981), Oregon, USA (Hotz, 1967), Burma (Schellmann, 1989) and Cameroon (YongueFouateu et al. 2006).

\section{A.3.7. Pyrrhotite. (Table A3)}

Some pyrrhotites (FeS) may contain significant amounts of $\mathrm{Ni}$. These are high temperature rocks. They are high temperature sulfides precipitated from magmas formed at depth in the mantle. We considered a set of pyrrhotite analyses from Oshirabetsu mine, Hokkaido (Bamba, 1981).

\section{A4. Results}

A4.1. Bronze Age Artifacts (Table A4)

Gerzeh beads. Several spots were analyzed on each of the three different beads from the Petrie Museum (UCL, London). The Ni contents (corrected on an oxygen free basis) vary from 3.6 to 8.5 with an average value of $5.7 \% \mathrm{Ni}$. This can be compared to the 0.9 to $4.8 \% \mathrm{Ni}$ measured by EDS (Energy dispersive spectrometry) in an SEM (scanning electron microscope) over rastered areas $0.25 \times 0.20$ $\mathrm{mm}^{2}$ by Johnson et al. (2013) on the bead preserved in Manchester Museum and 4.7 to $6.8 \%$ by PGAA on Petrie Museum beads (Rehren et al. 2013).

The analyses of Rehren et al. (2013) on the same beads and those of Johnson el al. (2013) are completely consistent with the p-XRF data once the effects of weathering are accounted for. The penetration depth of the analyses (PGAA>p-XRF> EDS-SEM) is another important parameter since outer layers are more affected by weathering.

Umm el Marra pendant. This specimen is highly weathered with an apparent density of $2.4 \mathrm{~g} / \mathrm{cm}^{3}$ (instead of 8 for fresh meteoritic iron). It is the sample exhibiting the highest state of weathering considered in this study.

The magnetic susceptibility was measured with a portable susceptibility probe SM30, according to the procedures given by Gattacceca et al. (2004). One finds a value of $\log \chi=4.9\left(10^{-9} \mathrm{~m}^{3} / \mathrm{kg}\right)$. This value is far higher than that of any terrestrial rock, which excludes a terrestrial origin. For a meteorite this would correspond to an ordinary chondrite of type $L$. According to the state of weathering, and the total amount of $\mathrm{Fe}(47.8 \%)$, it is more reasonable to interpret this value as representing some residual metal. This estimate can be done from the experiments of Rochette et al. (2009) and one obtains about 15 wt. \% metal confirming that the sample was 
highly, but not completely weathered. The Ni content is quite low ( 0.8 to $3.2 \% \mathrm{Ni}$ on an oxygen free basis). Literature data. We restricted our compilation to sufficiently well preserved artifacts (those containing some preserved metal) analyzed for $\mathrm{Fe}, \mathrm{Co}$ and $\mathrm{Ni}$. The number of such cases is very limited but we hope that this may change drastically on a short time scale. Among those are prestigious artifacts: Tutankhamen's dagger (Comelli et al. 2016; Ströbele et al. 2016,), Chinese axes (Li Chung, 1979) and the Alaça Höyük dagger (Nakai et al. 2008).

Tut's dagger is obviously the best preserved iron as discussed recently by Comelli et al. (2016) with a fresh meteoritic composition, quite high in $\mathrm{Ni}$. We notice that the composition given by Comelli is quite high in $\mathrm{Ni}(10.8 \%)$ and within error and/or variability similar to that of Ströbele et al. (2016) (12.9\%), therefore unambiguously meteoritic, compared to the previous results of Helmi and Barakat (1995) giving only $2.8 \% \mathrm{Ni}$ (Co was not documented). This again indicates that the idea of a threshold value is meaningless. Interestingly Horus eye (on the bracelet) and the miniature headrest exhibit significantly less nickel. According to their exceptional state of preservation we can say that, because of their significantly different compositions, that the dagger is not made from the same meteorite as the other two objects. The dagger is homogeneous (Standard Deviation of 1.1\%) in relation with its high $\mathrm{Ni}$ content (small size of the exsolution domains). Both the Horus eye (S.D. $=4.8$ $\%$ ) and the headrest (S.D. $=7.2 \%$ ) are far less homogeneous. This suggests that the Widmanstätten pattern is still present and coarser. The low Ni phase (kamacite) cannot be much different from $5 \% \mathrm{Ni}$, whereas the $\mathrm{Ni}$ rich phase (taenite) is less homogenous with on the average about $20 \% \mathrm{Ni}$. The more $\mathrm{Ni}$ rich metal (on average) corresponds to a larger fraction of taenite and a larger variability in the composition, at the scale of analysis $(4 \mathrm{~mm}$ diameter). The slightly different compositions and variabilities suggest that the headreast and the Horus eye were also made from two different meteorites. In others words Tutankamun's treasure was the first meteorite collection ever! A set of 16 additional iron miniature artifacts are presently investigated and may add to the list ( $F$. Stroebele, pers. com).

The Chinese axe from Shang dynasty $\left(14^{\text {th }}\right.$ century $\mathrm{BC}$ ) at Kao Ch'eng (Hopei, China) studied by $\mathrm{Li}$ Chung (1979) is not as well preserved but careful analysis showed the presence of residual metal. Unlike the Zhou axes (see below) this one is undoubtedly from the Bronze Age. The typology is typically one of the Bronze Age with a bronze socket cast around an iron blade. According to Li Chung (1979) metallographic investigations on the blade structure indicate a meteoritic structure. The $\mathrm{Ge}$ content exceeds 100 ppm, a meteoritic signature. The $\mathrm{Ni}$ and $\mathrm{Co}$ contents average (0.8-4\% and 0.2-0.4 $\%$ respectively on an oxygen free basis). Despite a significant uncertainty the $\mathrm{Ni} / \mathrm{Co}$ and $\mathrm{Ni} / \mathrm{Fe}$ plot along the meteoritic correlation with a lower than meteoritic $\mathrm{Ni}$ content.

The Alaca Höyük dagger is the worst preserved among those three. Still, Nakai et al. (2008) report variable $\mathrm{Ni}$ contents from 2.4 to $5.99 \%$, with the higher value in the meteoritic range. The calculation of the Co concentration is not documented (see A2.1) and according to the severe interference between $\mathrm{Fe}$ and $\mathrm{Co}$ this point is critical. Their $\mathrm{Ni} / \mathrm{Co}$ ratios range 15-26 suggesting a factor of two in their Co estimates. The high $\mathrm{Ni}$ concentration suggests a typical meteoritic composition but because of the possible analytical bias the Co data were not considered.

\section{A4.2. Iron Age artifacts (Table A5) Literature data \\ Fragments from Kaman Kalehöyük} (Turkey). (Akanuma, 2006). The only objects, which were not pervasively oxidized $(0<10 \%)$ are dated from the Iron Age (stratum II a and c). The chemical composition exhibits very low contents of both $\mathrm{Ni}$ $(<0.08 \%)$ with low $\mathrm{Ni} / \mathrm{Fe}(<0.001)$ and Co with a high $\mathrm{Co} / \mathrm{Ni}$ ratio (>0.8). This composition is that of typical smelted iron, as expected from Iron Age artifacts. Some of the compositions are comparatively high in $\mathrm{Ni}$ (up to $0.7 \%$ ), which may correspond to a $\mathrm{Ni}$ rich iron ore.

Western European irons. The irons of Manching, Germany (Schwab et al. 2006) are low in $\mathrm{Ni}$ (between 100 and $1600 \mathrm{ppm}$ ), the Co/Ni ratio are on the order of $0.5-1.0$, typical values for smelted irons. The iron objects analyzed by Brauns et al. (2013) (2 from Renningen and one from Grösseltal, both Germany) are low in Ni (300-1000 ppm) with Co/Ni ranging 0.2 to 0.5 .

Finally the more recent objects from DevélierCourtetelle (Jura, Switzerland), a set of 67 objects, analyzed by Eschenlohr et al., (2007) are low in $\mathrm{Ni}$ (40-4000 ppm; average 1200 ppm) with a Co/Ni ratio ranging 0.02 to 3 (average 0.43 )

For these three sets the corresponding fields are well separated from the meteoritic composition field. 


\begin{tabular}{|c|c|c|c|c|c|c|c|c|c|}
\hline Specimen & surface type & $\mathrm{Fe}$ & Co & $\mathrm{Ni}$ & Specimen & surface type & $\mathrm{Fe}$ & Co & $\mathrm{Ni}$ \\
\hline Agoudal & cleaned & 91.30 & 0.69 & 8.01 & Morasko & polished & 92.09 & 0.49 & 7.42 \\
\hline Agoudal & oxidized & 93.10 & 0.73 & 6.17 & Morasko & polished & 92.16 & 0.50 & 7.34 \\
\hline Agoudal & oxidized & 94.97 & 0.89 & 4.14 & Morasko & polished & 91.31 & 0.53 & 8.15 \\
\hline Agoudal & oxidized & 92.17 & 0.65 & 7.18 & Morasko & average & 91.79 & 0.53 & 7.69 \\
\hline Campo del Cielo & rough & 93.45 & 0.42 & 6.13 & Mundrabilla & polished & 94.65 & 0.71 & 4.64 \\
\hline Campo del Cielo & rough & 93.19 & 0.53 & 6.28 & Mundrabilla & rough & 94.10 & 0.79 & 5.11 \\
\hline Campo del Cielo & rough & 92.09 & 0.50 & 7.41 & Nantan & rough & 92.50 & 0.46 & 7.04 \\
\hline Campo del Cielo & rough & 92.43 & 0.44 & 7.14 & NWA 854 ZIZ & oxidized & 94.30 & 0.50 & 5.20 \\
\hline Canyon Diablo & oxidized & 95.06 & 0.44 & 4.50 & NWA 854 ZIZ & oxidized & 94.33 & 0.49 & 5.18 \\
\hline Canyon Diablo & oxidized & 92.05 & 0.51 & 7.44 & NWA 859 Taza & oxidized & 52.25 & 0.72 & 47.03 \\
\hline Canyon Diablo & oxidized & 94.37 & 0.57 & 5.06 & NWA 859 Taza & oxidized & 80.94 & 0.79 & 18.27 \\
\hline Canyon Diablo & oxidized & 92.70 & 0.46 & 6.84 & NWA 859 Taza & oxidized & 81.22 & 0.65 & 18.13 \\
\hline Canyon Diablo & oxidized & 90.25 & 0.63 & 9.12 & NWA 859 Taza & oxidized & 89.11 & 1.82 & 9.07 \\
\hline Cape of Good Hope & polished & 83.16 & 0.78 & 16.07 & NWA 859 Taza & oxidized & 89.28 & 1.82 & 8.90 \\
\hline Chinga & oxidized & 87.67 & 0.72 & 11.61 & NWA 859 Taza & oxidized & 89.80 & 1.77 & 8.43 \\
\hline Chinga & oxidized & 80.05 & 0.69 & 19.26 & NWA 5549 IAB-MG & oxidized & 92.88 & 0.45 & 6.67 \\
\hline Copiapo & polished & 93.90 & 0.51 & 5.59 & NWA 5549 IAB-MG & oxidized & 91.99 & 0.76 & 7.25 \\
\hline Gebel Kamil & polished & 75.93 & 1.21 & 22.86 & NWA 5549 IAB-MG & oxidized & 92.40 & 0.69 & 6.91 \\
\hline Gebel Kamil & rough & 75.50 & 1.19 & 23.31 & NWA 5549 IAB-MG & oxidized & 92.40 & 0.66 & 6.94 \\
\hline Gebel Kamil & rough & 77.00 & 1.18 & 21.82 & NWA 5549 IAB-MG & oxidized & 92.12 & 0.72 & 7.16 \\
\hline Gebel Kamil & rough & 80.09 & 0.96 & 18.95 & NWA 5549 IAB-MG & oxidized & 93.56 & 0.52 & 5.92 \\
\hline Gebel Kamil & rough & 80.73 & 0.97 & 18.30 & NWA unclassified & polished & 91.35 & 0.52 & 8.13 \\
\hline Gebel Kamil & rough & 82.56 & 1.83 & 15.61 & Sikhote Alin & rough & 93.90 & 0.57 & 5.53 \\
\hline Juromenha & polished & 94.31 & 0.51 & 5.18 & Sikhote Alin & rough & 94.60 & 0.54 & 4.86 \\
\hline Juromenha & polished & 90.73 & 0.51 & 8.76 & Sikhote Alin & rough & 92.56 & 0.60 & 6.84 \\
\hline Morasko & weathered & 86.37 & 0.78 & 12.86 & Sikhote Alin & rough & 92.42 & 0.52 & 7.06 \\
\hline Morasko & weathered & 91.20 & 0.69 & 8.12 & Sikhote Alin & rough & 93.82 & 0.47 & 5.71 \\
\hline Morasko & weathered & 90.70 & 0.61 & 8.68 & UAI & polished & 74.83 & 0.86 & 24.31 \\
\hline Morasko & weathered & 98.75 & 0.32 & 0.92 & UAI & oxidized & 86.11 & 0.96 & 12.93 \\
\hline Morasko & weathered & 95.46 & 0.40 & 4.14 & UAI & oxidized & 72.89 & 0.80 & 26.31 \\
\hline Morasko & weathered & 92.19 & 0.57 & 7.24 & UAI & oxidized & 74.75 & 0.81 & 24.44 \\
\hline Morasko & weathered & 92.77 & 0.43 & 6.80 & UAI & oxidized & 75.67 & 0.76 & 23.57 \\
\hline Morasko & weathered & 94.91 & 0.26 & 4.83 & Standard & & & & \\
\hline Morasko & weathered & 93.42 & 0.50 & 6.08 & $0 \mathrm{Ni}$ & polished & 99.74 & $\mathrm{BDL}$ & $\mathrm{BDL}$ \\
\hline Morasko & weathered & 91.69 & 0.59 & 7.72 & $10 \mathrm{Ni}$ & polished & 90.27 & $\mathrm{BDL}$ & 9.73 \\
\hline Morasko & polished & 92.59 & 0.38 & 7.03 & $10 \mathrm{Ni}$ & polished & 90.29 & $\mathrm{BDL}$ & 9.71 \\
\hline Morasko & polished & 92.37 & 0.47 & 7.15 & $17 \mathrm{Ni}$ & polished & 82.42 & $\mathrm{BDL}$ & 17.58 \\
\hline Morasko & polished & 92.45 & 0.64 & 6.91 & $17 \mathrm{Ni}$ & polished & 82.40 & $\mathrm{BDL}$ & 17.60 \\
\hline Morasko & polished & 91.86 & 0.48 & 7.66 & $30 \mathrm{Ni}$ & polished & 69.89 & $\mathrm{BDL}$ & 30.11 \\
\hline Morasko & polished & 86.84 & 0.64 & 12.52 & $30 \mathrm{Ni}$ & polished & 69.88 & $\mathrm{BDL}$ & 30.12 \\
\hline Morasko & polished & 90.49 & 0.68 & 8.83 & Irons average & & & & \\
\hline Morasko & polished & 92.11 & 0.51 & 7.39 & $\mathrm{IAB}$ & & 93.14 & 0.46 & 6.40 \\
\hline Morasko & polished & 92.42 & 0.55 & 7.03 & IC & & 92.44 & 0.46 & 7.10 \\
\hline Morasko & polished & 92.54 & 0.48 & 6.98 & $\| A B$ & & 93.32 & 0.53 & 6.15 \\
\hline Morasko & polished & 92.09 & 0.59 & 7.32 & IIC & & 88.55 & 0.65 & 10.80 \\
\hline Morasko & polished & 90.31 & 0.50 & 9.18 & IID & & 88.33 & 0.47 & 11.20 \\
\hline Morasko & polished & 91.62 & 0.55 & 7.83 & IIE & & 90.40 & 0.47 & 9.13 \\
\hline Morasko & polished & 92.33 & 0.51 & 7.16 & IIF & & 86.40 & 0.70 & 12.90 \\
\hline Morasko & polished & 92.50 & 0.46 & 7.04 & IIIAB & & 91.01 & 0.50 & 8.49 \\
\hline Morasko & polished & 93.40 & 0.45 & 6.15 & IIIE & & 91.01 & 0.50 & 8.49 \\
\hline Morasko & polished & 92.22 & 0.54 & 7.23 & IIIF & & 91.69 & 0.36 & 7.95 \\
\hline Morasko & polished & 91.78 & 0.47 & 7.75 & IVA & & 91.60 & 0.40 & 8.00 \\
\hline Morasko & polished & 92.22 & 0.55 & 7.23 & IVB & & 82.16 & 0.74 & 17.10 \\
\hline
\end{tabular}

Table A1 : p-XRF analyses of reference iron specimens of the present study. All totals normalized to $100 \%$. Average irons (bottom) are for NAA analyses from the literature (Willis et al. 1980 in Mittlefehldt et al. 1998). BDL = below detection limit. 


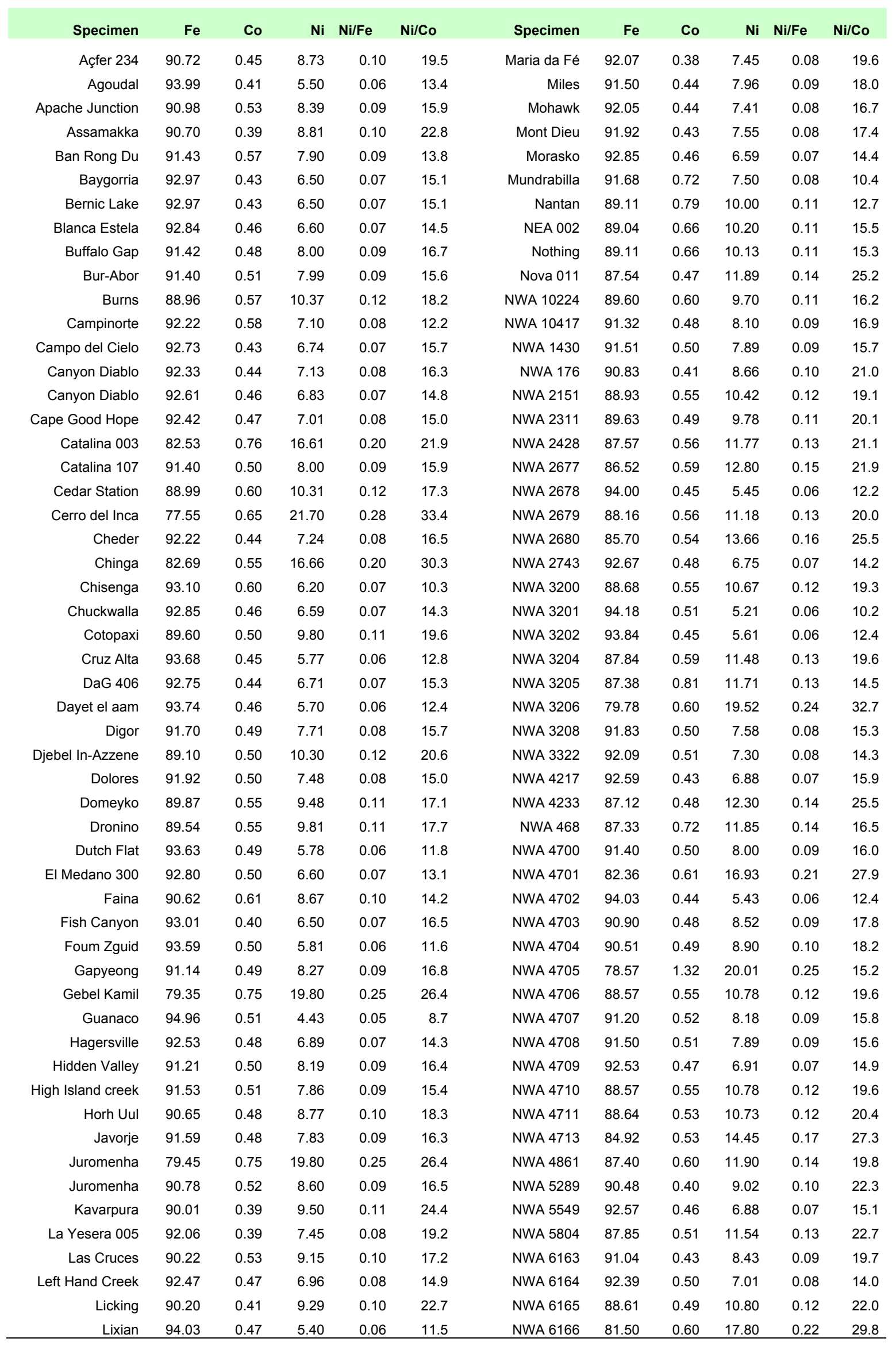

Table A2 (part 1). Iron compositions according to the Met Bull data base : 1986-2016 


\begin{tabular}{|c|c|c|c|c|c|c|c|c|c|c|c|}
\hline Specimen & $\mathrm{Fe}$ & Co & $\mathrm{Ni}$ & $\mathrm{Ni} / \mathrm{Fe}$ & $\mathrm{Ni} / \mathrm{Co}$ & Specimen & $\mathrm{Fe}$ & Co & $\mathrm{Ni}$ & $\mathrm{Ni} / \mathrm{Fe}$ & $\mathrm{Ni} / \mathrm{Co}$ \\
\hline Longtian & 92.09 & 0.50 & 7.32 & 0.08 & 14.8 & NWA 6203 & 93.18 & 0.44 & 6.28 & 0.07 & 14.2 \\
\hline NWA 6583 & 81.47 & 0.43 & 18.00 & 0.22 & 41.9 & Oglat Sidi Ali & 84.66 & 1.17 & 14.07 & 0.17 & 12.0 \\
\hline NWA 6716 & 91.71 & 0.42 & 7.77 & 0.08 & 18.4 & Pontes e lacerda & 91.31 & 0.49 & 8.10 & 0.09 & 16.5 \\
\hline NWA 6931 & 92.47 & 0.45 & 6.98 & 0.08 & 15.5 & Prospector Pool & 90.53 & 0.44 & 8.94 & 0.10 & 20.6 \\
\hline NWA 6932 & 86.95 & 0.68 & 12.27 & 0.14 & 17.9 & Qijiaojing & 88.76 & 0.54 & 10.60 & 0.12 & 19.8 \\
\hline NWA 7335 & 88.08 & 0.84 & 10.98 & 0.12 & 13.1 & Rainy River & 92.21 & 0.46 & 7.23 & 0.08 & 15.6 \\
\hline NWA 7795 & 85.83 & 0.47 & 13.60 & 0.16 & 28.8 & Sahara 03505 & 90.47 & 0.41 & 9.02 & 0.10 & 21.8 \\
\hline NWA 8154 & 94.16 & 0.47 & 5.27 & 0.06 & 11.1 & Santo Antonio d. & 93.68 & 0.46 & 5.76 & 0.06 & 12.5 \\
\hline NWA 8302 & 93.75 & 0.45 & 5.70 & 0.06 & 12.6 & Shawnee & 92.04 & 0.46 & 7.40 & 0.08 & 16.1 \\
\hline NWA 8337 & 88.27 & 0.45 & 11.18 & 0.13 & 25.0 & Sikhote Alin & 92.67 & 0.46 & 6.88 & 0.07 & 15.1 \\
\hline NWA 8346 & 90.99 & 0.48 & 8.43 & 0.09 & 17.6 & Sikhote Alin & 93.73 & 0.47 & 5.70 & 0.06 & 12.1 \\
\hline NWA 8347 & 91.47 & 0.44 & 7.99 & 0.09 & 18.2 & Sikhote Alin & 93.58 & 0.38 & 5.94 & 0.06 & 15.6 \\
\hline NWA 8348 & 84.70 & 0.55 & 14.65 & 0.17 & 26.7 & Tamarack & 93.54 & 0.50 & 5.86 & 0.06 & 11.7 \\
\hline NWA 8370 & 90.93 & 0.53 & 8.44 & 0.09 & 16.0 & Tarahumara & 91.52 & 0.47 & 7.91 & 0.09 & 16.8 \\
\hline NWA 8442 & 91.42 & 0.50 & 7.98 & 0.09 & 15.9 & Tartak & 92.03 & 0.50 & 7.37 & 0.08 & 14.7 \\
\hline NWA 8443 & 89.81 & 0.50 & 9.59 & 0.11 & 19.0 & Tequisquiapan & 93.05 & 0.39 & 6.46 & 0.07 & 16.6 \\
\hline NWA 8444 & 92.33 & 0.50 & 7.07 & 0.08 & 14.2 & Tongan & 92.87 & 0.43 & 6.60 & 0.07 & 15.2 \\
\hline NWA 8719 & 91.62 & 0.50 & 7.78 & 0.08 & 15.4 & Whitecourt & 91.30 & 0.50 & 8.11 & 0.09 & 16.4 \\
\hline NWA 959 & 89.99 & 0.43 & 9.48 & 0.11 & 22.2 & Willow Grove & 70.79 & 1.21 & 27.90 & 0.39 & 23.1 \\
\hline NWA 968 & 86.11 & 0.55 & 13.25 & 0.15 & 24.3 & Yarovoye & 89.93 & 0.52 & 9.45 & 0.11 & 18.2 \\
\hline NWA8441 & 87.43 & 0.52 & 11.95 & 0.14 & 23.1 & Yuanyang & 92.42 & 0.46 & 7.02 & 0.08 & 15.2 \\
\hline Ocate & 92.44 & 0.47 & 6.99 & 0.08 & 15.0 & Zapaliname & 92.74 & 0.46 & 6.70 & 0.07 & 14.7 \\
\hline
\end{tabular}

Table A2 (part 2). Iron compositions according to the Met Bull data base : 1986-2016

\begin{tabular}{cccccccc}
\hline sample \# & $\mathrm{S}$ & $\mathrm{Fe}$ & $\mathrm{Co}$ & $\mathrm{Ni}$ & Total & $\mathrm{Ni} / \mathrm{Co}$ & $\mathrm{Ni} / \mathrm{Fe}$ \\
\hline 29 & 38.51 & 60.25 & 0.05 & 0.95 & 99.76 & 19.0 & 0.016 \\
36 & 38.52 & 60.83 & 0.02 & 0.47 & 99.84 & 23.5 & 0.008 \\
45 & 39.19 & 58.78 & 0.10 & 1.09 & 99.16 & 10.9 & 0.019 \\
89 & 38.23 & 59.88 & 0.06 & 1.08 & 99.25 & 18.0 & 0.018 \\
55 & 38.70 & 60.19 & 0.02 & 0.79 & 99.70 & 39.5 & 0.013 \\
12 & 38.60 & 61.63 & 0.06 & 0.51 & 100.80 & 8.5 & 0.008 \\
44 & 38.61 & 61.57 & 0.04 & 0.02 & 100.24 & 0.5 & 0.000 \\
51 & 37.88 & 61.74 & 0.10 & 0.52 & 100.24 & 5.2 & 0.008 \\
\hline
\end{tabular}

Table A3. Chemical composition of pyrrhotites from the Oshirabetsu Mine, Hokkaido (Japan). (Bamba, 1981) 


\begin{tabular}{|c|c|c|c|c|c|c|c|c|}
\hline Specimen & & $\mathrm{Fe}$ & Co & $\mathrm{Ni}$ & Locality & Age BCE & analysis \# & ref \\
\hline RS9-250 & axe $A$ & 90.16 & 0.54 & 6.55 & Ugarit & 1350 & 217 & 1,2 \\
\hline RS9-250 & axe $A$ & 89.43 & 0.43 & 2.99 & Ugarit & 1350 & 218 & 1,2 \\
\hline RS9-250 & axe $A$ & 91.38 & 0.36 & 2.32 & Ugarit & 1350 & 219 & 1,2 \\
\hline RS9-250 & axe $A$ & 80.33 & 0.46 & 3.01 & Ugarit & 1350 & 220 & 1,2 \\
\hline RS9-250 & axe $A$ & 65.64 & 0.47 & 1.72 & Ugarit & 1350 & 221 & 1,2 \\
\hline RS9-250 & axe $B$ & 89.57 & 0.40 & 4.43 & Ugarit & 1350 & 224 & 1,2 \\
\hline RS9-250 & axe B & 89.58 & 0.46 & 5.44 & Ugarit & 1350 & 225 & 1,2 \\
\hline RS9-250 & axe $B$ & 92.46 & 0.41 & 4.71 & Ugarit & 1350 & 226 & 1,2 \\
\hline RS9-250 & axe $B$ & 91.97 & 0.57 & 4.54 & Ugarit & 1350 & 227 & 1,2 \\
\hline RS9-250 & axe $B$ & 87.67 & 0.63 & 7.59 & Ugarit & 1350 & 228 & 1,2 \\
\hline Petrie 10738 & Bead & 92.47 & 0.58 & 3.45 & Gerzeh & 3200 & 281 & $3,4,5$ \\
\hline Petrie 10738 & Bead & 86.24 & 0.99 & 8.10 & Gerzeh & 3200 & 282 & $3,4,5$ \\
\hline Petrie 10739 & Bead & 81.37 & 0.73 & 5.24 & Gerzeh & 3200 & 283 & $3,4,5$ \\
\hline Petrie 10740 & Bead & 89.18 & 0.54 & 4.53 & Gerzeh & 3200 & 284 & $3,4,5$ \\
\hline M00299 & pendant & 95.18 & 0.53 & 2.62 & Umm el Marra & 2500 & 209 & 6,7 \\
\hline M00299 & pendant & 93.95 & 0.59 & 2.63 & Umm el Marra & 2500 & 210 & 6,7 \\
\hline M00299 & pendant & 97.22 & 0.40 & 0.84 & Umm el Marra & 2500 & 211 & 6,7 \\
\hline M00299 & pendant & 91.20 & 0.42 & 1.14 & Umm el Marra & 2500 & 212 & 6,7 \\
\hline M00299 & pendant & 95.77 & 0.49 & 2.52 & Umm el Marra & 2500 & 213 & 6,7 \\
\hline M00299 & pendant & 92.96 & 0.63 & 3.21 & Umm el Marra & 2500 & 214 & 6,7 \\
\hline M00299 & pendant & 92.29 & 0.37 & 1.31 & Umm el Marra & 2500 & 215 & 6,7 \\
\hline M00299 & pendant & 95.69 & 0.58 & 1.87 & Umm el Marra & 2500 & 216 & 6,7 \\
\hline M00299 & pendant & 96.23 & 0.46 & 2.99 & Umm el Marra & 2500 & 233 & 6,7 \\
\hline Tut's dagger & blade & 88.57 & 0.58 & 10.85 & Thebes & 1350 & $p-X R F$ & 8 \\
\hline Tut's dagger & blade & 86.70 & 0.58 & 12.91 & Thebes & 1350 & $p-X R F$ & 12 \\
\hline Tut'sbracelet & Horus eye & 90.03 & 0.49 & 8.03 & Thebes & 1350 & $p-X R F$ & 12 \\
\hline Tut's & Headrest & 90.51 & 0.47 & 8.76 & Thebes & 1350 & $p-X R F$ & 12 \\
\hline Al.K.14 & Dagger & 97.41 & - & 2.43 & Alaca Höyük & 2400 & $\mathrm{p}-\mathrm{XRF} \# 1$ & 9 \\
\hline Al.K.14 & Dagger & 95.68 & - & 4.07 & Alaca Höyük & 2400 & p-XRF \#2 & 9 \\
\hline Al.K.14 & Dagger & 93.78 & - & 5.99 & Alaca Höyük & 2400 & p-XRF \#3 & 9 \\
\hline Al.K.14 & Dagger & 95.31 & - & 4.50 & Alaca Höyük & 2400 & $\mathrm{p}-\mathrm{XRF} \# 4$ & 9 \\
\hline Shang axe & blade & 91.10 & 0.40 & 3.40 & Kao Ch'eng & 14th cent. & wet chemical & 10 \\
\hline Shang axe & blade & 96.84 & 0.21 & 1.95 & Kao Ch'eng & 14th cent. & XRF & 10 \\
\hline Zhou axe 34.10 & Broad axe & 95.85 & 0.15 & 3.00 & Hunan & 10th cent. & wet chemical & 11 \\
\hline Zhou axe 34.10 & Broad axe & 88.31 & 0.21 & 11.47 & Hunan & 10th cent. & wet chemical & 11 \\
\hline Zhou axe 34.10 & Bd axe oxide & 87.62 & 0.39 & 11.99 & Hunan & 10th cent. & wet chemical & 11 \\
\hline Zhou axe 34.10 & Bd axe oxide & 88.44 & 0.26 & 11.30 & Hunan & 10th cent. & wet chemical & 11 \\
\hline Zhou axe 34.10 & Bd axe oxide & 88.27 & 0.28 & 11.44 & Hunan & 10th cent. & wet chemical & 11 \\
\hline Zhou axe 34.10 & Bd axe oxide & 88.31 & 0.21 & 11.47 & Hunan & 10th cent. & wet chemical & 11 \\
\hline Zhou axe 34.10 & Bd axe Metal & 92.20 & 0.60 & 6.90 & Hunan & 10th cent. & EMPA & 11 \\
\hline Zhou axe 34.10 & Bd axe Metal & 92.60 & 0.70 & 6.70 & Hunan & 10th cent. & EMPA & 11 \\
\hline Zhou axe 34.10 & Bd axe Metal & 91.60 & 0.60 & 6.80 & Hunan & 10th cent. & EMPA & 11 \\
\hline Zhou axe 34.10 & Bd axe Metal & 65.30 & 0.30 & 23.00 & Hunan & 10th cent. & EMPA & 11 \\
\hline Zhou axe 34.10 & Bd axe Metal & 70.00 & 0.30 & 22.60 & Hunan & 10th cent. & EMPA & 11 \\
\hline Zhou axe 34.10 & Bd axe Metal & 62.40 & 0.30 & 27.30 & Hunan & 10th cent. & EMPA & 11 \\
\hline Zhou axe 34.10 & Bd axe Metal & 65.40 & 0.20 & 29.30 & Hunan & 10th cent. & EMPA & 11 \\
\hline Zhou axe 34.11 & Dagger axe & 98.45 & 0.05 & 0.50 & Hunan & 10th cent. & wet chemical & 11 \\
\hline Zhou axe 34.11 & Dagger axe & 98.85 & 0.07 & 1.08 & Hunan & 10th cent. & wet chemical & 11 \\
\hline Zhou axe 34.11 & Dagger axe & 86.00 & 0.40 & 5.20 & Hunan & 10th cent. & EMPA & 11 \\
\hline Zhou axe 34.11 & Dagger axe & 81.50 & 0.30 & 5.20 & Hunan & 10th cent. & EMPA & 11 \\
\hline
\end{tabular}

Table A4 : Present p-XRF analyses (top) and literature analyses of Bronze Age artifacts.

1 Schaeffer 1939

2 Jambon et al. 2017

3 Jambon 2010
4 Rehren et al. 2013
5 Johnson et al. 2013

6 Schwartz et al. 2003
7 Jambon 2017

8 Comelli et al. 2016

9 Nakai et al. 2008
10 Li Chung 1979

11 Gettens et al. 1971

12 Ströbele et al. 2016 


\begin{tabular}{|c|c|c|c|c|c|c|c|c|}
\hline Specimen & type & $\mathrm{Fe}$ & Co & $\mathbf{N i}$ & Locality & Age BCE & analysis \# & ref \\
\hline $\mathrm{p}-\mathrm{XRF}$ & detection limit & 0.24 & 0.05 & 0.02 & - & & & \\
\hline Zhou axe 34.10 & Braod axe & 95.85 & 0.15 & 3.00 & Honan & 10 th century & wet chem. & 11 \\
\hline Zhou axe 34.10 & Braod axe & 88.31 & 0.21 & 11.47 & Honan & 10 th century & wet chem. & 11 \\
\hline Zhou axe 34.10 & $\mathrm{Bd}$ axe oxide & 87.62 & 0.39 & 11.99 & Honan & 10 th century & wet chem. & 11 \\
\hline Zhou axe 34.10 & Bd axe oxide & 88.44 & 0.26 & 11.30 & Honan & 10 th century & wet chem. & 11 \\
\hline Zhou axe 34.10 & Bd axe oxide & 88.27 & 0.28 & 11.44 & Honan & 10 th century & wet chem. & 11 \\
\hline Zhou axe 34.10 & Bd axe oxide & 88.31 & 0.21 & 11.47 & Honan & 10 th century & wet chem. & 11 \\
\hline Zhou axe 34.10 & Bd axe metal & 92.20 & 0.60 & 6.90 & Honan & 10 th century & EMPA & 11 \\
\hline Zhou axe 34.10 & $\mathrm{Bd}$ axe metal & 92.60 & 0.70 & 6.70 & Honan & 10 th century & EMPA & 11 \\
\hline Zhou axe 34.10 & $\mathrm{Bd}$ axe metal & 91.60 & 0.60 & 6.80 & Honan & 10 th century & EMPA & 11 \\
\hline Zhou axe 34.10 & Bd axe metal & 65.30 & 0.30 & 23.00 & Honan & 10 th century & EMPA & 11 \\
\hline Zhou axe 34.10 & Bd axe metal & 70.00 & 0.30 & 22.60 & Honan & 10 th century & EMPA & 11 \\
\hline Zhou axe 34.10 & Bd axe metal & 62.40 & 0.30 & 27.30 & Honan & 10 th century & EMPA & 11 \\
\hline Zhou axe 34.10 & Bd axe metal & 65.40 & 0.20 & 29.30 & Honan & 10 th century & EMPA & 11 \\
\hline Zhou axe 34.11 & Dagger axe & 98.45 & 0.05 & 0.50 & Honan & 10 th century & wet chem. & 11 \\
\hline Zhou axe 34.11 & Dagger axe & 98.85 & 0.07 & 1.08 & Honan & 10 th century & wet chem. & 11 \\
\hline Zhou axe 34.11 & Dagger axe & 86.00 & 0.40 & 5.20 & Honan & 10 th century & EMPA & 11 \\
\hline Zhou axe 34.11 & Dagger axe & 81.50 & 0.30 & 5.20 & Honan & 10 th century & EMPA & 11 \\
\hline AUV-2242 Latenium & pin & 93.17 & bdl & bdl & Neuchatel & $950-850$ & \#283 & 12 \\
\hline AUV-2242 Latenium & pin & 96.15 & bdl & bdl & Neuchatel & $950-850$ & \#285 & 12 \\
\hline AUV-2290 Latenium & hook & 87.17 & bdl & bdl & Neuchatel & $950-850$ & \#286 & 12 \\
\hline AUV-2736 Latenium & nail & 96.64 & bdl & bdl & Neuchatel & $950-850$ & \#287 & 12 \\
\hline AUV-2740 Latenium & nail head & 97.06 & 0.17 & 0.09 & Neuchatel & $950-850$ & \#288 & 12 \\
\hline AUV-2740 Latenium & nail head & 96.98 & bdl & bdl & Neuchatel & $950-850$ & \#289 & 12 \\
\hline AUV-2740 Latenium & nail head & 95.33 & bdl & bdl & Neuchatel & $950-850$ & \#290 & 12 \\
\hline AUV-2740 Latenium & nail head & 96.00 & bdl & bdl & Neuchatel & $950-850$ & \#291 & 12 \\
\hline HR-93 Latenium & pin & 91.66 & 0.35 & bdl & Neuchatel & $950-850$ & \#292 & 12 \\
\hline HR-93 Latenium & pin & 89.14 & 0.38 & bdl & Neuchatel & $950-850$ & \#293 & 12 \\
\hline HR-93 Latenium & pin & 90.67 & 0.19 & bdl & Neuchatel & $950-850$ & \#295 & 12 \\
\hline HR-93 Latenium & pin & 91.84 & 0.31 & bdl & Neuchatel & $950-850$ & \#296 & 12 \\
\hline HR-110 Latenium & long pin & 82.11 & 0.68 & bdl & Neuchatel & $950-850$ & \#297 & 12 \\
\hline HR-110 Latenium & long pin & 95.80 & 0.23 & bdl & Neuchatel & $950-850$ & \#298 & 12 \\
\hline HR-110 Latenium & long pin & 93.96 & 0.51 & bdl & Neuchatel & $950-850$ & $\# 299$ & 12 \\
\hline HR-110 Latenium & long pin & 92.61 & 0.49 & bdl & Neuchatel & $950-850$ & $\# 300$ & 12 \\
\hline AO22953 le_Louvre & Halberd sideA & 89.00 & 0.35 & bdl & Luristan & IA transition & \#587 & 12 \\
\hline AO22953 le_Louvre & Halberd sideA & 91.99 & 0.31 & bdl & Luristan & IA transition & \#588 & 12 \\
\hline AO22953 le_Louvre & Halberd sideA & 90.72 & 0.30 & bdl & Luristan & IA transition & \#589 & 12 \\
\hline AO22953 le_Louvre & Halberd sideB & 88.83 & 0.36 & bdl & Luristan & IA transition & \#591 & 12 \\
\hline AO20882 le_Louvre & Adze side A & 79.53 & bdl & bdl & Luristan & IA transition & \#592 & 12 \\
\hline AO20882 le_Louvre & Adze side A & 84.89 & 0.26 & bdl & Luristan & IA transition & \#593 & 12 \\
\hline AO20882 le_Louvre & Adze side B & 85.77 & 0.32 & bdl & Luristan & IA transition & \#594 & 12 \\
\hline N-1 Latenium & adze & 96.68 & 0.21 & bdl & Sweden & $?$ & \#301 & 12 \\
\hline $\mathrm{N}-1$ Latenium & adze & 96.98 & 0.48 & bdl & Sweden & $?$ & \#302 & 12 \\
\hline $\mathrm{N}-1$ Latenium & adze & 96.28 & 0.56 & bdl & Sweden & $?$ & \#303 & 12 \\
\hline Gresham ship UCL & bloomery iron & 98.81 & 0.10 & 0.00 & London & ca. $1580 \mathrm{AD}$ & \#131 & 13 \\
\hline Gresham ship UCL & bloomery iron & 98.85 & 0.20 & 0.02 & London & ca. $1580 \mathrm{AD}$ & \#132 & 13 \\
\hline Gresham ship UCL & bloomery iron & 98.88 & 0.19 & 0.01 & London & ca. $1580 \mathrm{AD}$ & $\# 133$ & 13 \\
\hline M1 St_Germain-en-laye & Ingot 01 & 86.12 & 0.45 & 0.27 & Marsal & ca 600 BCE & $\# 178$ & 14 \\
\hline M1 St_Germain-en-laye & Ingot 01 & 94.73 & 0.29 & 0.21 & Marsal & ca 600 BCE & $\# 179$ & 14 \\
\hline M1 St_Germain-en-laye & Ingot 01 & 93.24 & 0.30 & 0.16 & Marsal & ca 600 BCE & \#180 & 14 \\
\hline M1 St_Germain-en-laye & Ingot 01 & 96.00 & 0.28 & 0.16 & Marsal & ca 600 BCE & $\# 181$ & 14 \\
\hline M1 St_Germain-en-laye & Ingot 01 & 92.52 & 0.33 & 0.20 & Marsal & ca $600 \mathrm{BCE}$ & Mean & 14 \\
\hline
\end{tabular}

Table A5 (part 1): $p-X R F$ analyses of transition and Iron Age specimens discussed during this study. 12 This study (p-XRF) 14 Bertaux (1990) and Olivier (pers. com. 2016) 13 Auer and Firth (2007) 


\begin{tabular}{|c|c|c|c|c|c|c|c|c|}
\hline Specimen & type & $\mathrm{Fe}$ & Co & $\mathbf{N i}$ & Locality & Age BCE & analysis \# & ref \\
\hline M2 St_Germain-en-laye & Ingot 02 & 97.11 & 0.15 & bdl & Marsal & ca 600 BCE & $\# 182$ & 14 \\
\hline M2 St_Germain-en-laye & Ingot 02 & 97.72 & 0.09 & bdl & Marsal & ca 600 BCE & $\# 183$ & 14 \\
\hline M2 St_Germain-en-laye & Ingot 02 & 92.90 & 0.23 & bdl & Marsal & ca 600 BCE & $\# 184$ & 14 \\
\hline M2 St_Germain-en-laye & Ingot 02 & 96.88 & 0.20 & bdl & Marsal & ca 600 BCE & $\# 185$ & 14 \\
\hline M2 St_Germain-en-laye & Ingot 02 & 96.15 & 0.17 & bdl & Marsal & ca 600 BCE & Mean & 14 \\
\hline M3 St_Germain-en-laye & Ingot 03 & 97.98 & 0.15 & bdl & Marsal & ca 600 BCE & $\# 186$ & 14 \\
\hline M3 St_Germain-en-laye & Ingot 03 & 97.67 & 0.14 & 0.16 & Marsal & ca 600 BCE & $\# 187$ & 14 \\
\hline M3 St_Germain-en-laye & Ingot 03 & 97.98 & 0.08 & 0.00 & Marsal & ca 600 BCE & $\# 188$ & 14 \\
\hline M3 St_Germain-en-laye & Ingot 03 & 98.40 & 0.07 & 0.20 & Marsal & ca 600 BCE & $\# 189$ & 14 \\
\hline M3 St_Germain-en-laye & Ingot 03 & 98.01 & 0.11 & 0.12 & Marsal & ca 600 BCE & Mean & 14 \\
\hline M4 St_Germain-en-laye & Ingot 04 & 97.37 & 0.00 & bdl & Marsal & ca 600 BCE & $\# 192$ & 14 \\
\hline M4 St_Germain-en-laye & Ingot 04 & 95.94 & 0.10 & bdl & Marsal & ca 600 BCE & \#193 & 14 \\
\hline M4 St_Germain-en-laye & Ingot 04 & 97.50 & 0.08 & bdl & Marsal & ca 600 BCE & $\# 194$ & 14 \\
\hline M4 St_Germain-en-laye & Ingot 04 & 95.50 & 0.09 & bdl & Marsal & ca 600 BCE & \#195 & 14 \\
\hline M4 St_Germain-en-laye & Ingot 04 & 96.58 & 0.07 & bdl & Marsal & ca 600 BCE & Mean & 14 \\
\hline M5 St_Germain-en-laye & Ingot 05 & 98.64 & bdl & bdl & Marsal & ca 600 BCE & $\# 170$ & 14 \\
\hline M5 St_Germain-en-laye & Ingot 05 & 97.38 & bdl & bdl & Marsal & ca 600 BCE & $\# 171$ & 14 \\
\hline M5 St_Germain-en-laye & Ingot 05 & 98.18 & bdl & bdl & Marsal & ca 600 BCE & $\# 172$ & 14 \\
\hline M5 St_Germain-en-laye & Ingot 05 & 98.83 & 0.26 & bdl & Marsal & ca 600 BCE & $\# 173$ & 14 \\
\hline M5 St_Germain-en-laye & Ingot 05 & 98.26 & 0.26 & bdl & Marsal & ca 600 BCE & Mean & 14 \\
\hline M6 St_Germain-en-laye & Ingot 06 & 92.41 & 0.19 & 0.14 & Marsal & ca 600 BCE & $\# 174$ & 14 \\
\hline M6 St_Germain-en-laye & Ingot 06 & 97.71 & 0.13 & 0.28 & Marsal & ca 600 BCE & $\# 175$ & 14 \\
\hline M6 St_Germain-en-laye & Ingot 06 & 97.60 & 0.11 & 0.17 & Marsal & ca 600 BCE & $\# 176$ & 14 \\
\hline M6 St_Germain-en-laye & Ingot 06 & 96.51 & 0.33 & 0.37 & Marsal & ca 600 BCE & $\# 177$ & 14 \\
\hline M6 St_Germain-en-laye & Ingot 06 & 96.06 & 0.19 & 0.24 & Marsal & ca 600 BCE & Mean & 14 \\
\hline Bloomery iron & polished & 97.85 & bdl & 0.09 & Morocco & $?$ & $\# 136$ & 13 \\
\hline Bloomery iron & oxidized & 83.28 & 0.05 & 0.11 & Morocco & $?$ & $\# 137$ & 13 \\
\hline Bloomery iron & oxidized & 90.40 & 0.17 & bdl & Morocco & $?$ & $\# 134$ & 13 \\
\hline Bloomery iron & oxidized & 94.32 & 0.15 & bdl & Morocco & $?$ & $\# 135$ & 13 \\
\hline Bloomery iron & polished & 99.82 & 0.18 & bdl & Morocco & $?$ & $\# 162$ & 13 \\
\hline Cz.I-9:60 & bracelet & 78.20 & 0.49 & 15.50 & Czestochowa & Hallstatt D & $\# 417$ & 15 \\
\hline Cz.I-9:60 & bracelet & 80.70 & 0.66 & 17.50 & Czestochowa & Hallstatt D & $\# 418$ & 15 \\
\hline Cz.I-9:60 & bracelet & 77.20 & 0.61 & 18.40 & Czestochowa & Hallstatt D & \#419 & 15 \\
\hline Cz.I-9:60 & bracelet & 78.70 & 0.59 & 17.13 & Czestochowa & Hallstatt D & Mean & 15 \\
\hline Cz.I-294:61 & bracelet & 78.90 & 0.60 & 18.10 & Czestochowa & Hallstatt D & $\# 12$ & 15 \\
\hline Cz.I-294:61 & bracelet & 75.90 & 0.73 & 21.20 & Czestochowa & Hallstatt D & $\# 13$ & 15 \\
\hline Cz.I-294:61 & bracelet & 77.40 & 0.67 & 19.65 & Czestochowa & Hallstatt D & Mean & 15 \\
\hline polished section & axe & 92.11 & 0.29 & 7.60 & Wietrzno & Hallstatt C & $\# 29$ & 15 \\
\hline polished section & axe & 92.91 & 0.22 & 6.87 & Wietrzno & Hallstatt C & \#34 & 15 \\
\hline polished section & axe & 93.21 & 0.20 & 6.59 & Wietrzno & Hallstatt C & \#35 & 15 \\
\hline polished section & axe & 94.50 & 0.25 & 5.25 & Wietrzno & Hallstatt C & \#14 & 15 \\
\hline polished section & axe & 93.18 & 0.24 & 6.58 & Wietrzno & Hallstatt C & Mean & 15 \\
\hline
\end{tabular}

Table A5 (part 2): $\mathrm{p}-\mathrm{XRF}$ analyses of Iron Age specimens discussed during this study. 14 Bertaux (1990) and Olivier (pers. com. 2016) 15 Piaskowki (1982) 